\title{
Ion Implantation for the Fabrication of Plasmonic Nanocomposites: A Brief Review
}

\author{
Umapada Pal ${ }^{1}$ and Ovidio Peña Rodríguez ${ }^{2}$ \\ ${ }^{1}$ Instituto de Física, Benemérita Universidad Autónoma de Puebla, Puebla \\ ${ }^{2}$ Centro de Microanálisis de Materiales (CMAM), \\ Universidad Autónoma de Madrid (UAM), Cantoblanco, Madrid \\ Instituto de Óptica, Consejo Superior de Investigaciones Científicas (IO-CSIC), \\ C/ Serrano Madrid \\ ${ }^{1}$ Mexico \\ 2Spain
}

\section{Introduction}

Metal nanoparticles (NPs) have been the subject of intense research in recent years, largely due to their characteristic surface plasmon resonance (SPR), a phenomenon arising from the collective oscillation of their conduction electrons. The SPR characteristics of metal NPs have been exploited to utilize them in medical diagnostics (Allain \& Vo-Dinh, 2002), immunoassay (Hirsch et al., 2003a; Cui et al., 2006), cancer treatments (Hirsch et al., 2003b; Zhang, 2010), biological or chemical sensing (Sun \& Xia, 2002; Alivisatos, 2004; Cao et al., 2009), and surface enhanced Raman scattering (SERS) (Jackson \& Halas, 2004). Large thirdorder optical susceptibility and picosecond optical response of metal NPs made them excellent candidates for non-linear optical devices (Mazzoldi et al., 1996; White et al., 1998; Pavesi et al., 2000; Borsella et al., 2001). Strong SPR-induced optical absorption of these nanostructures has also been utilized to enhance their photocatalytic activity (Tihay et al., 2001) and to increase the efficiency of dye-sensitized solar cells (Catchpole \& Polman, 2008; Atwater \& Polman, 2010; Ding et al., 2011).

Frequently these NPs are incorporated into dielectric or semiconducting matrices to fabricate dielectric-metal or semiconductor-metal nanocomposites with the aim of manipulating their functionalities, exploiting the characteristics of both the matrix and the metal NPs. Among the nanocomposites, those in which the SPR effect is prominent are called plasmonic nanocomposites (PNCs). Frequently these nanocomposites are fabricated by incorporating nanoparticles of noble metals like $\mathrm{Au}, \mathrm{Ag}$ and $\mathrm{Cu}$ in insulating matrices like silica $\left(\mathrm{a}-\mathrm{SiO}_{2}\right)$, quartz $\left(\mathrm{c}-\mathrm{SiO}_{2}\right)$, and other metal oxides like zinc oxide $(\mathrm{ZnO})$, alumina $\left(\mathrm{Al}_{2} \mathrm{O}_{3}\right)$, and titania $\left(\mathrm{TiO}_{2}\right)$. Though, in principle, several other metal particles can be used for the fabrication of PNCs this is seldom done, due to their high proneness to oxidation or interband transitions in the usable spectral range. Consequently, in this short review we will mainly focus on these three important metals.

Two characteristics, particularly important for practical use of plasmonic nanocomposites, are: the location of the SPR in the desired spectral position and a high optical extinction. For 
the very small metal NPs (i.e. those much smaller than the optical wavelength) the extinction is dominated by absorption and the absorption coefficient $(\alpha)$ can be expressed as (Arnold \& Borders, 1977):

$$
\propto\left(\mathrm{cm}^{-1}\right)=\frac{18 \pi \mathrm{Q} \mathrm{n}_{\mathrm{d}}^{3}}{\lambda} \frac{\varepsilon_{2}}{\left(\varepsilon_{1}+2 \mathrm{n}_{\mathrm{d}}^{2}\right)^{2}+\varepsilon_{2}^{2}}
$$

where $Q$ is the volume fraction occupied by the metallic nanoparticles, $n_{d}$ is the refractive index of the host matrix, $\varepsilon_{1}$ and $\varepsilon_{2}$ are the real and imaginary parts of the dielectric constant of the bulk metal, respectively, and $\lambda$ is the optical wavelength. The value of $\alpha$ becomes maximum at the surface plasmon frequency $\left(\omega_{S P R}\right)$, when

$$
\varepsilon_{1}\left(\omega_{S P R}\right)+2 \mathrm{n}_{\mathrm{d}}^{2}=0 .
$$

As we see, the SPR frequency of metal nanoparticles depends on both the optical constant of bulk metal and the refractive index of the host matrix. Estimating the wavelength variation of $\varepsilon_{1}$ from the optical constants given by Johnson and Christy (Johnson \& Christy, 1972) for $\mathrm{Au}, \mathrm{Ag}$, and $\mathrm{Cu}$, and refractive indices of common oxide matrices we can calculate the position of the SPR band for different nanocomposites, as presented in Table 1. Though the position of SRP in different nanocomposites depends also on the size and size distribution of the metal NPs, for which we must introduce size correction terms (Hövel et al., 1993) in equation (2), we can see that the tabulated SPR energies are in good agreement with the reported values for the nanocomposites fabricated by different methods (Ballesteros et al., 1997; De, 1997; Pal et al., 2000, 2001; Vazquez-Cuchillo et al., 2001; Wang et al., 2003; GarcíaSerrano \& Pal, 2003; Barreca et al., 2004; Subramanian et al., 2004; Zeng et al., 2004; Hazra et al., 2004; Okumu et al., 2005; Ryasnyansky et al., 2005; Serna et al., 2006; Sonawane \& Dongare, 2006; Mishra et al., 2008; Zheng et al., 2008; Kalidindi \& Jagirdar, 2008; Kim et al., 2008; Manoilov, 2009; Jiang et al., 2009; Ma et al., 2009; Sangpour et al., 2010; Tohidi et al., 2010; Duhan et al., 2010). As the absorption coefficient depends on the volume fraction occupied by metallic NPs in the composites (eq. 1), the intensity of the SPR band increases on increasing the amount of incorporated metal NPs.

Several methods have been utilized to fabricate plasmonic nanocomposites like cosputtering, ion-implantation, sol-gel, laser ablation, etc. (De, 1997; Pal et al., 2000; GarcíaSerrano \& Pal, 2003; Barreca et al., 2004; Kim et al., 2008; Manoilov, 2009). However, irrespective of the fabrication method, practical application of these materials strongly depends on parameters like the size and shape of the incorporated metal NPs, volume fraction occupied by them, homogeneity of NP distribution, and their composition. In this respect, each of the utilized methods has certain constrains. Although ion-implantation is not as versatile as other techniques used for the fabrication of plasmonic nanocomposites, it still has several attractive advantages. For example, ion implantation followed by an additional thermal annealing has proven to be a very useful method to obtain large volume fractions of NPs embedded in solid matrices. Additionally, those NPs are located in a well defined depth below the surface, chosen mainly by the ion energy (Oliver et al., 2002). Some other advantages of ion implantation include controllability of depth profile and concentration, high purity, and the possibility to overcome low solubility restrictions. Particularly, deep ion implantation using energies of the order of $\mathrm{MeV}$ produces an ion 
depth distribution located some micrometers underneath the surface and wide enough to be convenient for the production of optical waveguides. Ion implantation has been also successfully used to create more complex structures such as alloys (Mattei, 2002), sophisticated aggregates (Mattei et al., 2003b; Pellegrini et al., 2007a, 2007b), core-shell structures (Peña et al., 2009) and nanorods (which are aligned, unlike those produced by other methods) (Rodríguez-Iglesias et al., 2010a; b).

In this chapter, we intend to review the current status of the synthesis of plasmonic nanocomposites by means of ion-implantation. In the year 1984, Picraux (Picraux, 1984) has published a useful review on the status of ion-implantation in metals, improving the understanding on the kinetics and equilibria in metal alloy reactions, surface modification, and defect structures. Similarly, Buchal et al. (Buchal et al., 1994) have reviewed the status of ion-implantation in optical materials in 1994, focusing mainly on the usefulness of the technique for producing linear and non-linear optical devices. However, apart from a good review on $\mathrm{Cu}$ implanted alumina by Stepanov and Khaibullin (Stepanov \& Khaibullin, 2005) there exists no recent review summarizing the current advances made on the utilization of this technique for the fabrication and processing of plasmonic nanocomposites which have emerging applications in diverse fields.

\begin{tabular}{|c|c|c|c|c|}
\hline $\begin{array}{l}\text { Incorporated } \\
\text { species }\end{array}$ & $\begin{array}{l}\text { Matrix material } \\
\text { (refractive index) }\end{array}$ & $\begin{array}{l}\text { Predicted } \\
(\mathrm{eV})\end{array}$ & $\begin{array}{l}\text { Measured } \\
(\mathrm{eV})\end{array}$ & References \\
\hline $\mathbf{A u}$ & $\mathrm{SiO}_{2}(1.48)$ & 2.35 & $2.48-2.21$ & $\begin{array}{l}\text { (Barreca et al., 2004; } \\
\text { Kim et al., 2008) }\end{array}$ \\
\hline Ag & $\mathrm{SiO}_{2}(1.48)$ & 3.12 & $3.92-3.02$ & $\begin{array}{l}\text { (Roiz et al., 2004; Ma et } \\
\text { al., 2009; Duhan et al., } \\
\text { 2010) }\end{array}$ \\
\hline $\mathrm{Cu}$ & $\mathrm{SiO}_{2}(1.48)$ & 2.70 & 2.31-1.59 & $\begin{array}{c}\text { (De, 1997; Peña et al., } \\
\text { 2006; Tohidi et al., 2010) }\end{array}$ \\
\hline $\mathrm{Au}$ & $\mathrm{Al}_{2} \mathrm{O}_{3}(1.76)$ & 2.24 & $2.38-1.79$ & $\begin{array}{l}\text { (García-Serrano \& Pal, } \\
\text { 2003; Hazra et al., 2004) }\end{array}$ \\
\hline Ag & $\mathrm{Al}_{2} \mathrm{O}_{3}(1.76)$ & 2.85 & $3.08-2.06$ & $\begin{array}{l}\text { (Zeng et al., 2004; } \\
\text { Manoilov, 2009) } \\
\end{array}$ \\
\hline $\mathrm{Cu}$ & $\mathrm{Al}_{2} \mathrm{O}_{3}(1.76)$ & 2.20 & $2.10-2.00$ & $\begin{array}{l}\text { (Ballesteros et al., 1997; } \\
\text { Serna et al., 2006) }\end{array}$ \\
\hline $\mathrm{Au}$ & $\mathrm{ZnO}(2.00)$ & 2.14 & $2.48-2.25$ & $\begin{array}{l}\text { (Wang et al., 2003; } \\
\text { Mishra et al., 2008) }\end{array}$ \\
\hline Ag & $\mathrm{ZnO}(2.00)$ & 2.64 & $2.91-2.53$ & $\begin{array}{c}\text { (Shan et al., 2007; Zheng } \\
\text { et al., 2008) }\end{array}$ \\
\hline $\mathrm{Cu}$ & $\mathrm{ZnO}(2.00)$ & 2.09 & $2.14-2.06$ & $\begin{array}{l}\text { (Ryasnyansky et al., } \\
\text { 2005; Kalidindi \& } \\
\text { Jagirdar, 2008) }\end{array}$ \\
\hline $\mathbf{A u}$ & $\mathrm{TiO}_{2}(2.80)$ & 1.80 & $2.34-1.83$ & $\begin{array}{c}\text { (Subramanian et al., } \\
\text { 2004; Sonawane \& } \\
\text { Dongare, 2006) } \\
\end{array}$ \\
\hline Ag & $\mathrm{TiO}_{2}(2.80)$ & 2.09 & $2.58-2.10$ & $\begin{array}{l}\text { (Okumu et al., 2005; } \\
\text { Jiang et al., 2009) }\end{array}$ \\
\hline $\mathrm{Cu}$ & $\mathrm{TiO}_{2}(2.80)$ & 1.82 & 2.15 & (Sangpour et al., 2010) \\
\hline
\end{tabular}

Table 1. SPR positions in common plasmonic nanocomposites. 


\section{Implantation of metal ions in dielectrics}

Since long ago, ion implantation has been used to modify the optical properties of materials. Dielectrics such as silica glass $\left(\mathrm{SiO}_{2}\right)$, alumina $\left(\mathrm{Al}_{2} \mathrm{O}_{3}\right)$, and quartz have been used traditionally for this purpose; but recently several other metal oxides like $\mathrm{ZnO}$ and $\mathrm{TiO}_{2}$ have also been utilized. Historically, ion implantation has been used to change the optical properties of dielectric target materials like reflectivity, absorption, refractive index, luminescence, and electro-optic coefficients (Mazzoldi, 1987; Townsend, 1987). Those modifications are not only associated to the implanted species, but also to a number of other phenomena occurring during the process like radiation damage caused by the ion beam, and formation of colloidal precipitates of the implanted species with diameters in between 2 and $20 \mathrm{~nm}$ (Hughes, 1983). As the mechanism of formation of radiation damages and their elimination processes have been widely discussed in the literature (Agulló-López et al., 1988; Pal et al., 2000; Bianconi et al., 2009; Rivera et al., 2010), we will concentrate our discussion on the latter mechanism only.

In fact, the formation of colloidal precipitate of metals like Au and Ag has been utilized for hundreds of years to design beautiful colored glasses (Bamford, 1977). While the color of the implanted dielectrics depends mostly on the implanted species (metals) and to some extent the size of the formed colloidal particles, their intensity/contrast depends on the volume fraction occupied by the colloidal precipitates in the matrix. So, apart from the nature of implanted metal, a control over the implanted dose (amount of implanted species incorporated into the dielectric matrix) is essential to control the optical properties of the substrates (dielectrics). In contrast to the conventional melt growth process, where only about $1 \%$ of impurities (guest atoms) can be incorporated into a matrix, there is no such restriction in ion implantation, as the process occurs without thermodynamic restrictions.

For the ion implantation purpose, the ion beams of selected metals doses in the range of $10^{16}-10^{18} \mathrm{~cm}^{-2}$ have been utilized to expose solid target surfaces as big as a few $\mathrm{cm}^{2}$. In fact, the process has the ability to fabricate technological grade composite wafers with uniform distribution of metal NPs at precise depths below the target surface. The range of metal NP distribution, their occupied volume fraction, size (diameter), and composition can also be controlled by suitable adjustment of implantation parameters. In the following section, we will discuss how these parameters can be controlled and their effects on the characteristics of the final product (nanocomposites).

\subsection{Controlling parameters in ion implantation process}

Essentially any specie can be introduced into a solid matrix by means of ion implantation, thereby changing its physical properties. For this purpose, ions of the desired element are produced in an ionization chamber; then they are electrostatically accelerated to the desired energy and, finally, allowed to impinge on a solid target. As typically each ion is a single atom, the amount of material incorporated or implanted into the target can be precisely calculated by integrating the ion current over the exposure time. The amount incorporated is called dose or fluence. Generally the ion currents used for implantation are small, in the range of nano- to microamperes. Ion beam energies may vary from a few $\mathrm{keV}$ up to hundreds of $\mathrm{MeV}$, depending on the requirement, though energies in the range of a few $\mathrm{MeV}$ are commonly used to produce PNCs. Greater ion energy causes higher structural damage to the target. However, due to broader depth distribution, the change in chemical composition at a certain point in the target would be small. 
When high energy ions penetrate into a solid, they gradually lose energy due to non-elastic collisions with the free electrons of the solid and elastic collisions with the nuclei until they become immobilized. As the second process is an elastic one, most of the energy loss of the incident ion bean occurs very close to the surface of the solid, due to the first process. The penetration depth of the ions in the solid target depends on the ion energy, nature of ionic species, and the nature and composition of the target. Typically, the penetration depth or the range of the ions in a solid target varies in between a few nanometers to a few micrometers, and hence all the changes occurring during the implantation process remain near the surface of the target material (Figure 1).

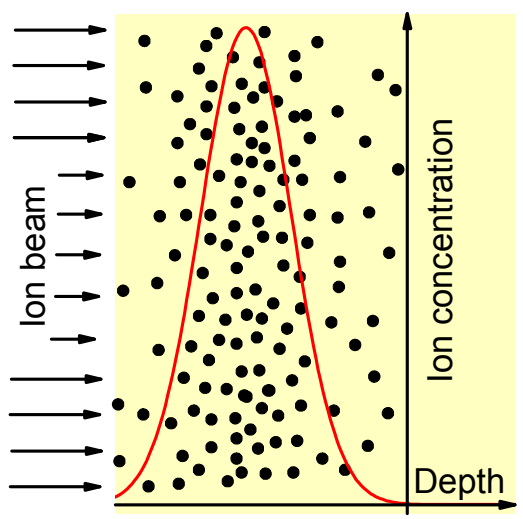

Fig. 1. Schematic presentation of the ion implantation process in a solid and the implantation profile.

Typical ion doses utilized for fabricating plasmonic nanocomposites vary in between $1.0 \times 10^{16} \mathrm{~cm}^{-2}$ and $2.0 \times 10^{17} \mathrm{~cm}^{-2}$. While a greater dose frequently induces the formation of undesired nanovoids or nanocavities in the target matrix (Kooi et al., 2000) or inside metal precipitates (particles) (Ren et al., 2006) due to aggregation of vacancies driven by the heat produced during the high-dose ion irradiation, lower doses frequently incorporate metallic species in ionic state inside the dielectric matrices (Haug et al., 2009). While higher ion energy enhances the penetration depth of the implanted species, a higher ion dose shifts the maximum of the distribution of the implanted species in the target towards lower depths, due to the diffusion to the heavily-damaged region produced just before the ions are stopped (Figure 2). Though the penetration depth of ionic species remains within a few micrometers beneath the surface of the implanted solid, it can extend to a larger depth on increasing the temperature of the solid target.

In the case of an amorphous solid target, the implanted ions get distributed randomly following a Gaussian profile inside the matrix, which can be expressed as:

$$
\mathrm{N}(\mathrm{x})=\mathrm{N}_{0} \exp \left[-\frac{\left(\mathrm{R}_{\mathrm{p}}-\mathrm{x}\right)^{2}}{2 \Delta \mathrm{R}_{\mathrm{p}}^{2}}\right]=\frac{\phi_{0}}{\sqrt{2 \pi \Delta \mathrm{R}_{\mathrm{p}}}} \exp \left[-\frac{\left(\mathrm{R}_{\mathrm{p}}-\mathrm{x}\right)^{2}}{2 \Delta \mathrm{R}_{\mathrm{p}}^{2}}\right]
$$

where $\mathrm{N}(x)$ is the concentration of ions at a distance $x$ from the surface; $\mathrm{N}_{0}$ is the concentration of ions at $x=\mathrm{R}_{\mathrm{p}}, \phi_{0}$ is the total implanted dose and $\mathrm{R}_{\mathrm{p}}$ is the effective range of 
penetration by an ion, dependent of real range $R_{c}$, where $R_{c}$, the real range of penetration, i.e. distance covered by the ion in the implanted solid, and $\Delta R_{p}$ is the standard deviation of the $R_{p}$ value. The location of $R_{p}$ depends predominantly on the energy of ions and their atomic mass. The relative dispersion of implanted specie, i.e. $\Delta R_{p} / R_{p}$ depends both on the atomic mass of the implanted species and the atomic mass of the solid target.
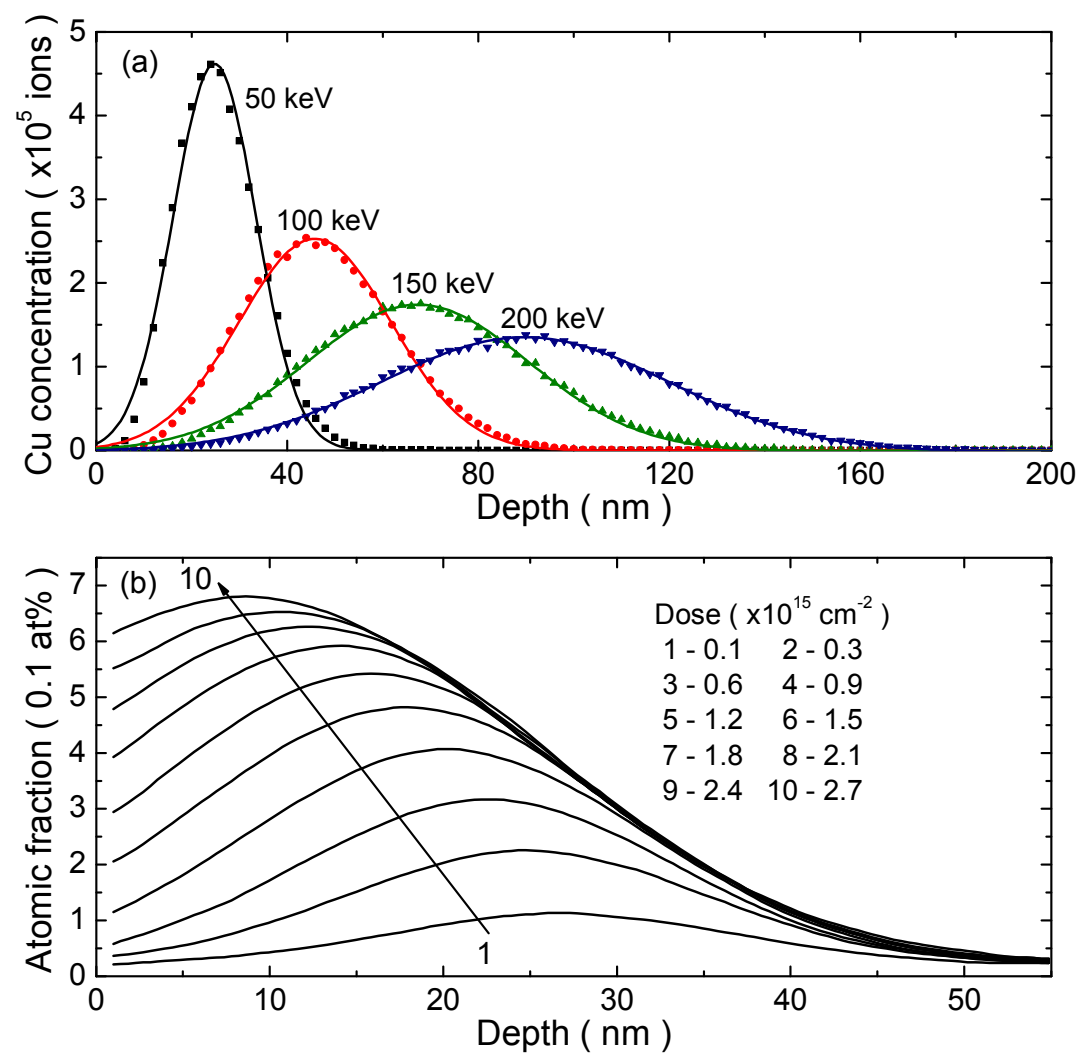

Fig. 2. a) Variation of profile and depth of implantation of $\mathrm{Cu}^{+}$ions into $\mathrm{Al}_{2} \mathrm{O}_{3}$ with the variation of ion energy, calculated using SRIM 2008 (Ziegler, 1985, 2008); b) Implantation depth versus dose, calculated using dynamic computer code DYNA of $\mathrm{Cu}^{+}$ions of $40 \mathrm{keV}$ in $\mathrm{Al}_{2} \mathrm{O}_{3}$. Adapted with permission from AIP Conf. Proc. 680 (2003) 601-604 (Stepanov \& Popok, 2003).

On the other hand, for the case of a crystalline solid target, the range of penetration and the implant distribution strongly depend on the orientation of the structure with respect to the direction of beam incidence. Generally the penetration depth or the implantation range is about one order higher when the ion beam is projected along a given crystallographic direction of the target like [111], [100], etc. (Burakowski \& Wierzchon, 1998). As can be seen from Figure 3, the defect distribution profile remains at a shallower level with respect to the implant distribution. 

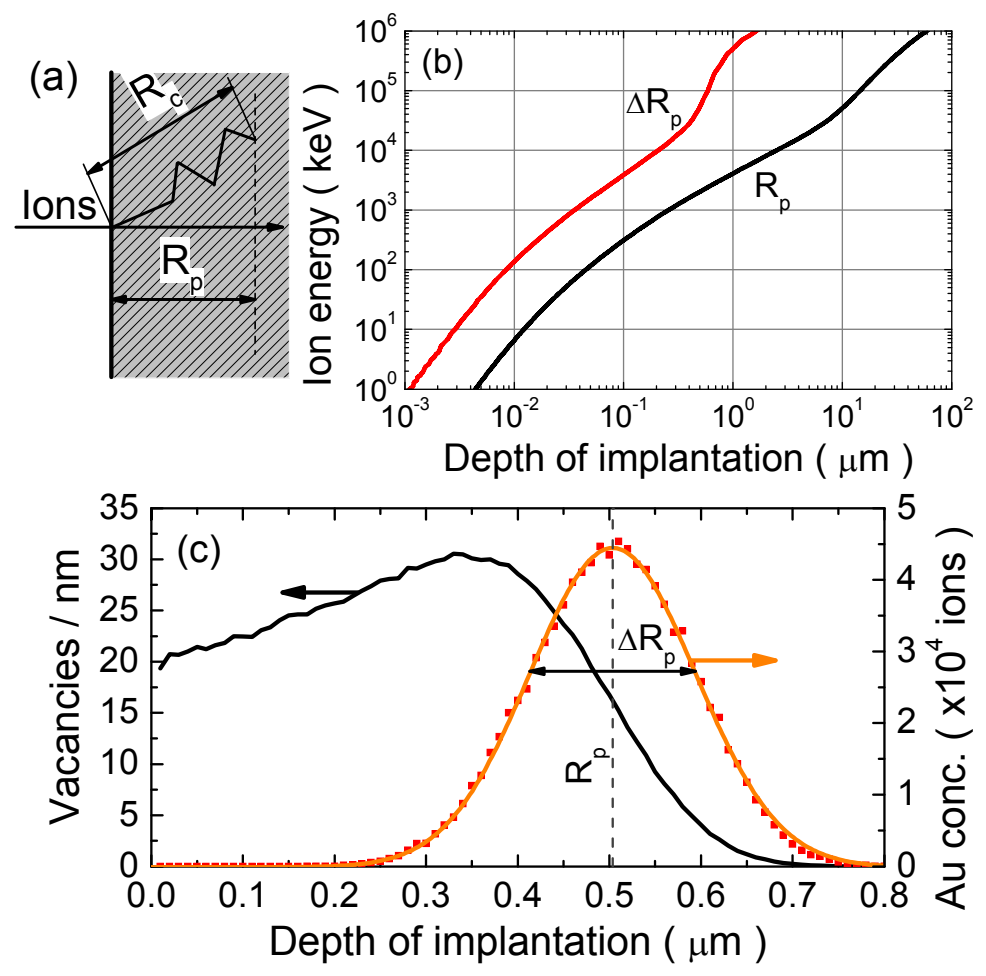

Fig. 3. a) Schematic illustration of the range of penetration; b) variation of implantation range $R_{p}$ and standard deviation $\Delta R_{p}$ with ion energy for $2 \mathrm{MeV}$ Au ions implanted in silica; c) distributions of implanted ions and defects. All simulations were performed using SRIM 2008 (Ziegler, 1985, 2008).

\section{Controlled growth of noble metal nanoparticles through ion-implantation}

The noble metals like $\mathrm{Au}, \mathrm{Ag}$ and $\mathrm{Cu}$ have been incorporated into dielectric matrices to produce several plasmonic nanocomposites with varied combinations of metals and dielectrics. The main objective of such works was to utilize the intense local field, strong linear optical absorption or SPR in applications such as optical sensing, biological and chemical sensing, and fabrication of all-optical devices. The electronic transitions responsible for plasmon absorption in metal NPs are also responsible for the generation of optical nonlinearities in the same spectral range, i.e. at the SPR position. To exploit the advantage of this SPR absorption in nanocomposites, it is desirable to have a high concentration of metal NPs (i.e., high filling factor) in the matrix (Flytzanis et al., 1991). Therefore, as has been mentioned earlier, apart from the adequate energy of implantation, a high dose of implanted ions is required. By the terms "high metal ion dose" $\phi_{0}$, we mean a dose exceeding the solubility limit of the metal atoms in the target (dielectric in the present case), which generally vary in between $10^{15}-10^{17} \mathrm{~cm}^{-2}$, depending on the nature of ion species and target materials. The characteristics of the incorporated metal NPs also depend 
on the utilized ion dose. While there is a limiting value of implanted dose for each combination of metal ions and target material to obtain well dispersed metal NPs with controlled nucleation and growth (i.e. with definite geometrical shape and size), doses higher than this limiting value cause aggregation or coalescence of the formed NPs, strongly affecting their optical properties (Figure 4). For example, for $25 \mathrm{keV} \mathrm{Ag}^{+}$ion implantation into $\mathrm{LiNbO}_{3}$, the limiting dose was found to be $\phi_{0} \sim 5.0 \times 10^{15} \mathrm{~cm}^{-2}$ (Deying et al., 1994), and $\sim 10^{16} \mathrm{~cm}^{-2}$ for $30 \mathrm{keV} \mathrm{Ag}{ }^{+}$ions in solid epoxy resin (Stepanov et al., 1995). In fact, the implantation range and concentration distribution of the metal NPs strongly depend on the implantation dose (Figure 2b).

Fabrication of plasmonic nanocomposites by ion implantation dates back to 1973, when Davenas and co-workers (Davenas et al., 1973) pioneered this method to fabricate metal NPs of silver, calcium, etc. inside crystalline $\mathrm{LiF}$ and $\mathrm{MgO}$ matrices. Later, the method was extended for the fabrication of other metal NPs in several other matrices like sapphire $\left(\mathrm{Al}_{2} \mathrm{O}_{3}\right)$, silica $\left(\mathrm{SiO}_{2}\right)$ and even polymers. For practical applications, plasmonic nanocomposites containing metal NPs of desired sizes, high filling fraction, and controlled composition are the basic requirements. While the ion implantation technique can introduce virtually any element in any matrix without solubility restrictions, the typical cluster size distributions in ion implanted nanocomposites are not narrow. On the other hand, progress has been made to fabricate metal-dielectric nanocomposites with controlled composition of metal NPs like elemental metallic clusters, bimetallic alloy clusters and core-shell type bimetallic nanoclusters. Depending on the nature of the metallic element and the matrix, adequate adjustments of implantation conditions (e.g. implantation energy, dose) and post implantation treatments (thermal annealing, laser annealing, etc.) in adequate atmosphere (e.g. oxidizing atmosphere like air or oxygen, inert atmosphere like argon and reducing atmosphere like hydrogen or a mixture of hydrogen and argon) are necessary to fabricate each type of the above mentioned architectures. In the following sections we will discuss on the fabrication of each of these nanoarchitectures, their plasmonic behaviors, and application potentials.

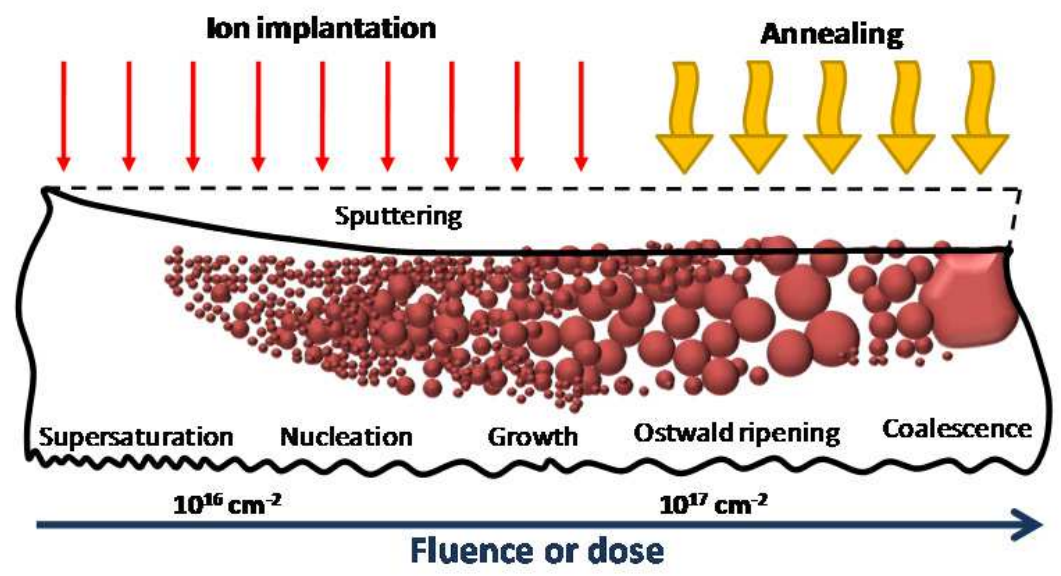

Fig. 4. Basic physical processes (left to right) involved in the formation of metal nanoparticles from an implant at different ion doses. 


\subsection{Formation of nanocomposites}

At a certain temperature, when the solute concentrations are above their solubility limits in a matrix, there occurs spontaneous condensation of solute. Within a homogeneous matrix and in conditions which may rule out coalescence, this condensation usually leads to the formation of spherical clusters. The theory of growth of spherical clusters has been developed and used by many authors (Lifshitz \& Slezov, 1959; Aaron et al., 1970). According to this theory, at relatively low temperatures (in comparison with the melting temperature of bulk materials), formed clusters predominantly go through a stage of nucleation and growth. The exact analytical solution of the growth process of a spherical cluster is very difficult to obtain. For this reason, various approaches have been used to represent the real solution to a greater or lesser extent. In particular, we want to solve the field equation:

$$
D \nabla^{2} C=\frac{\partial C}{\partial t}
$$

where $D$ is the volumetric coefficient of diffusion (assumed to be independent of position) and $C=C(r, t)$ is the field of concentration in the matrix around the precipitate. Also, the independent equation of flow balance must be satisfied:

$$
\left(C_{p}-C_{I}\right) \frac{d R}{d t}=\left.D \frac{\partial C}{\partial r}\right|_{r=R}
$$

$C_{P}$ is the concentration of the precipitate (constant), $C_{I}$ is the solute concentration in the matrix, at the precipitate-matrix interface and $R$ is the value of $r$ on that interface. For the condition $\left(C_{P}-C_{M}\right)>>\left(C_{I}-C_{M}\right)$, the $R(t)$ is a slowly varying function of time and a way to simplify the field equation (4) is by using the invariant-field approximation in time (Laplace approximation), which is $\partial C / \partial t=0$, thus being the Laplace equation $\nabla^{2} C=0$. Now, for the steady state of the cluster, we can solve the equation (4) to obtain:

$$
R=\lambda(D t)^{1 / 2}, \text { where } \lambda=(-k)^{\frac{1}{2}}, k=2 \frac{C_{I}-C_{M}}{C_{P}-C_{I}},
$$

where $C_{M}$ is the concentration of solute in the matrix far away from the precipitate. The problem is almost identical for the dissolution of clusters. In this case $R(t=0)=R_{0}>0$, we obtain the expression:

$$
R^{2}=R_{0}^{2}-k D t
$$

Note that $k$ is positive during the dissolution and negative during the growth.

\subsection{Fabrication of nanocomposites containing elemental noble metal clusters}

Controlling the plasmonic behavior of noble metal clusters (nanoparticles), i.e. their SPR position and intensity in nanocomposites is of immense importance for their practical applications. Manipulation of the implantation variables (energy and dose) coupled with a post-implantation annealing allows the fabrication of metal nanoclusters with the desired SPR characteristics. Since the first report on ion implantation fabrication of such nanocomposites 


\begin{tabular}{|c|c|c|c|c|c|}
\hline Metal & Matrix & $\begin{array}{l}\text { Ion energy } \\
(\mathrm{keV})\end{array}$ & $\begin{array}{l}\text { Dose } \\
\left(\mathrm{cm}^{-2}\right)\end{array}$ & $\begin{array}{l}\text { Post-implantation } \\
\text { annealing }\end{array}$ & References \\
\hline $\mathrm{Au}$ & $\mathrm{SiO}_{2}$ & 3000 & $6.0 \times 10^{15}$ & $\begin{array}{l}\text { in air, 550-750, } 1050 \\
{ }^{0} \mathrm{C}\end{array}$ & $\begin{array}{l}\text { (Mohapatra et al., } \\
\text { 2007) }\end{array}$ \\
\hline $\mathrm{Au}$ & $\mathrm{SiO}_{2}$ & 60 & $2.0 \times 10^{17}$ & - & (Takeda et al., 2006) \\
\hline $\mathbf{A u}$ & $\mathrm{SiO}_{2}$ & 2000 & $(0.7-6.0) \times 10^{16}$ & $\begin{array}{l}\text { in air \& }\left(\mathrm{N}_{2}+\mathrm{H}_{2}\right), 300- \\
1100^{\circ} \mathrm{C}, 1 \mathrm{~h}\end{array}$ & (Oliver et al., 2002) \\
\hline $\mathrm{Au}$ & $\mathrm{Al}_{2} \mathrm{O}_{3}$ & 400 & $6.8 \times 10^{16}$ & - & $\begin{array}{l}\text { (Ohkubo \& Suzuki, } \\
\text { 1988) }\end{array}$ \\
\hline $\mathrm{Au}$ & $\mathrm{Al}_{2} \mathrm{O}_{3}$ & 160 & $1.0 \times 10^{17}$ & - & (Marques et al., 2004) \\
\hline $\mathrm{Au}$ & $\mathrm{Al}_{2} \mathrm{O}_{3}$ & 2000 & $(0.2-2.0) \times 10^{17}$ & in air, $978-1323{ }^{\circ} \mathrm{C}, 1 \mathrm{~h}$ & (Ila et al., 1997) \\
\hline $\mathrm{Au}$ & $\mathrm{Al}_{2} \mathrm{O}_{3}$ & 1800 & $(0.1-1.0) \times 10^{18}$ & $1000^{\circ} \mathrm{C} \& 1200^{\circ} \mathrm{C}, 1 \mathrm{~h}$ & (Dhara et al., 2004) \\
\hline $\mathrm{Au}$ & $\mathrm{Al}_{2} \mathrm{O}_{3}$ & 60 & $2.0 \times 10^{17}$ & - & (Takeda et al., 2006) \\
\hline $\mathbf{A u}$ & $\mathrm{TiO}_{2}$ & 260 & $5.0 \times 10^{16}$ & - & (Zhu et al., 2006) \\
\hline$\overline{A u}$ & $\mathrm{TiO}_{2}$ & 1800 & $8.5 \times 10^{16}$ & $480^{\circ} \mathrm{C}$ & (Nakao et al., 2000) \\
\hline $\mathrm{Au}$ & $\mathrm{c}-\mathrm{TiO}_{2}$ & 2000 & $6.0 \times 10^{16}$ & $1002^{\circ} \mathrm{C}$ & $\begin{array}{l}\text { (Wang, 2004; Wang et } \\
\text { al., 2005) }\end{array}$ \\
\hline $\mathrm{Au}$ & $\mathrm{c}-\mathrm{ZnO}$ & 300 & $\begin{array}{l}8.0 \times 10^{13} \\
4.0 \times 10^{16}\end{array}$ & - & (Kucheyev et al., 2003) \\
\hline Ag & $\mathrm{SiO}_{2}$ & $\begin{array}{l}35,1700, \\
2400\end{array}$ & $(3.0-7.0) \times 10^{16}$ & in air, $500^{\circ} \mathrm{C}, 1 \mathrm{~h}$ & $\begin{array}{l}\text { (Joseph et al., 2007; } \\
\text { Xiao et al., 2007) }\end{array}$ \\
\hline Ag & $\mathrm{SiO}_{2}$ & 10 & $5.0 \times 10^{15}$ & in $\mathrm{Ar}, 500-800^{\circ} \mathrm{C}$ & (Arai et al., 2006) \\
\hline Ag & $\mathrm{SiO}_{2}$ & 200 & $\begin{array}{l}1.0 \times 10^{15} \\
1.0 \times 10^{17}\end{array}$ & - & (Liu et al., 2005) \\
\hline $\mathrm{Ag}$ & $\mathrm{SiO}_{2}$ & 2000 & $(0.7-6.0) \times 10^{16}$ & $\begin{array}{l}\text { in air \& }\left(\mathrm{N}_{2}+\mathrm{H}_{2}\right), 300- \\
1100^{\circ} \mathrm{C}, 1 \mathrm{~h}\end{array}$ & (Oliver et al., 2002) \\
\hline $\mathrm{Ag}$ & $\mathrm{Al}_{2} \mathrm{O}_{3}$ & $25-30$ & $(0.2-2.0) \times 10^{17}$ & & (Steiner et al., 1998) \\
\hline $\mathrm{Ag}$ & $\mathrm{Al}_{2} \mathrm{O}_{3}$ & 1500 & $(0.2-2.0) \times 10^{17}$ & in air, $773{ }^{\circ} \mathrm{C}, 1 \mathrm{~h}$ & (Ila et al., 1997) \\
\hline $\mathrm{Ag}$ & $\mathrm{Al}_{2} \mathrm{O}_{3}$ & 1800 & $1.2 \times 10^{17}$ & in air, $1100^{\circ} \mathrm{C}, 2 \mathrm{~h}$ & $\begin{array}{l}\text { (White et al., 1992, } \\
\text { 1993) }\end{array}$ \\
\hline Ag & $\mathrm{TiO}_{2}$ & 65 & $\begin{array}{l}3.0 \times 10^{16} \\
1.0 \times 10^{17}\end{array}$ & in air, $400^{\circ} \mathrm{C}$ & (Tsuji et al., 2002) \\
\hline $\mathrm{Ag}$ & $\mathrm{ZnO}$ & 30,60 & $(0.3-1.0) \times 10^{17}$ & - & (Zhou et al., 2011) \\
\hline Ag & $\mathrm{ZnO}$ & 20,40 & $(3.0-7.0) \times 10^{16}$ & - & (Xiao et al., 2010) \\
\hline Ag & $\mathrm{ZnO}$ & 40 & $1.0 \times 10^{16}$ & - & $\begin{array}{l}\text { (Mendoza-Galván et } \\
\text { al., 2006) }\end{array}$ \\
\hline $\mathrm{Cu}$ & $\mathrm{SiO}_{2}$ & 2000 & $(0.7-6.0) \times 10^{16}$ & $\begin{array}{l}\text { in air \& }\left(\mathrm{N}_{2}+\mathrm{H}_{2}\right), 300- \\
1100^{\circ} \mathrm{C}, 1 \mathrm{~h}\end{array}$ & (Oliver et al., 2002) \\
\hline $\mathrm{Cu}$ & $\mathrm{SiO}_{2}$ & 2000 & $6.0 \times 10^{16}$ & $\begin{array}{l}\text { in vacuum, } 600-800 \\
{ }^{\circ} \mathrm{C}, 1 \mathrm{~h}\end{array}$ & (Pan et al., 2007) \\
\hline $\mathrm{Cu}$ & $\mathrm{SiO}_{2}$ & 60 & $(0.5-2.0) \times 10^{17}$ & $\begin{array}{l}200 \text { to } 7000^{\circ} \mathrm{C} \text { for } 1 \mathrm{~h} \\
\text { per step with an } \\
\text { interval of } 100^{\circ} \mathrm{C}\end{array}$ & (Xu et al., 2006) \\
\hline $\mathrm{Cu}$ & $\mathrm{SiO}_{2}$ & 60 & $1.0 \times 10^{17}$ & - & (Bandourko et al., 2005) \\
\hline
\end{tabular}




\begin{tabular}{|c|c|c|c|c|c|}
\hline Metal & Matrix & $\begin{array}{l}\text { Ion energy } \\
\text { (keV) }\end{array}$ & $\begin{array}{l}\text { Dose } \\
\left(\mathrm{cm}^{-2}\right)\end{array}$ & $\begin{array}{l}\text { Post-implantation } \\
\text { annealing }\end{array}$ & References \\
\hline $\mathbf{C u}$ & $\mathrm{SiO}_{2}$ & 2000 & $(1.0-2.2) \times 10^{17}$ & in air, $600-1050^{\circ} \mathrm{C}, 1 \mathrm{~h}$ & (Pal et al., 2000) \\
\hline $\mathbf{C u}$ & $\mathrm{Al}_{2} \mathrm{O}_{3}$ & 110 & $1.0 \times 10^{17}$ & & (Donnet et al., 1991) \\
\hline $\mathrm{Cu}$ & $\mathrm{Al}_{2} \mathrm{O}_{3}$ & 160 & $(0.2-1.0) \times 10^{17}$ & in air, $673^{\circ} \mathrm{C}, 1 \mathrm{~h}$ & (Ila et al., 1997) \\
\hline $\mathbf{C u}$ & $\mathrm{Al}_{2} \mathrm{O}_{3}$ & 40 & $1.0 \times 10^{17}$ & & (Stepanov et al., 2001) \\
\hline $\mathrm{Cu}$ & $\mathrm{Al}_{2} \mathrm{O}_{3}$ & 2100 & $1.0 \times 10^{17}$ & $\begin{array}{l}\text { in vacuum, 497-997 } \\
{ }^{\circ} \mathrm{C}, 1 \mathrm{~h}\end{array}$ & (Ikeyama et al., 2001) \\
\hline $\mathrm{Cu}$ & $\mathrm{TiO}_{2}$ & 20 & $5.0 \times 10^{15}$ & - & (Wang et al., 2006) \\
\hline $\mathrm{Cu}$ & $\mathrm{TiO}_{2}$ & 60 & $1.0 \times 10^{17}$ & - & (Takeda et al., 2005) \\
\hline $\mathbf{C u}$ & $\mathrm{TiO}_{2}$ & 50 & $(0.3-1.0) \times 10^{17}$ & in air, $4000^{\circ} \mathrm{C}, \mathrm{XX}$ & (Tsuji et al., 2002) \\
\hline $\mathrm{Cu}$ & $\mathrm{ZnO}$ & 160 & $(0.1 \& 1.0) \times 10^{17}$ & - & $\begin{array}{l}\text { (Kono et al., 2003; } \\
\text { Norton et al., 2003; } \\
\text { Stepanov et al., 2004) }\end{array}$ \\
\hline
\end{tabular}

Table 2. List of noble metal ions used to incorporate in common oxide matrices with different implantation conditions and post implantation treatments.

by Davenas' group in 1973 (Davenas et al., 1973), a vast effort has been devoted to their controlled fabrication using different combinations of metal particles and matrices. As can be seen from table 2, Au, Ag and Cu NPs have been incorporated into several dielectric matrices with different implantation conditions and the conditions of subsequent annealing.
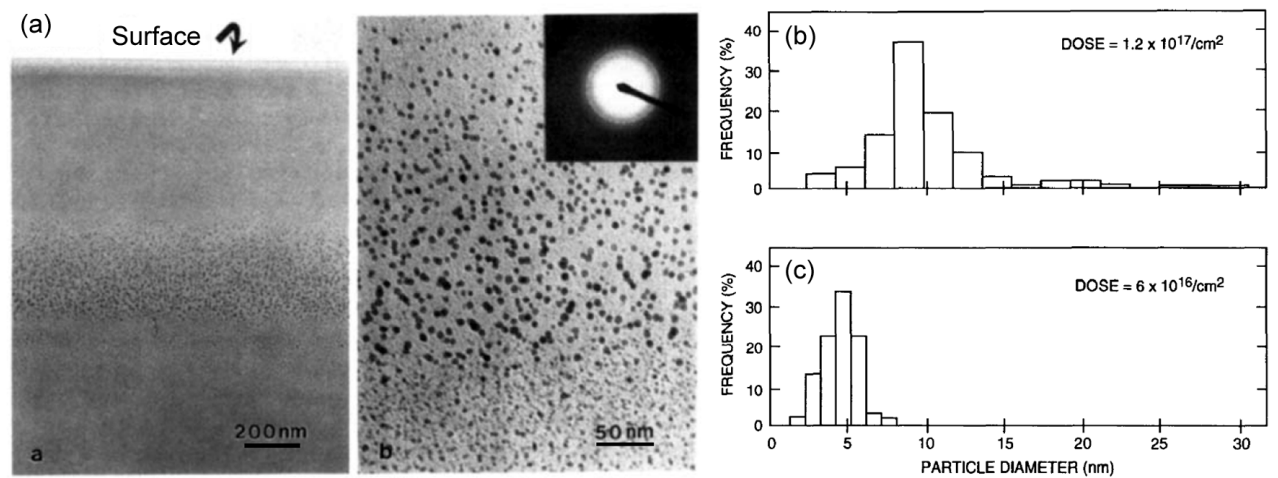

Fig. 5. Cross-sectional TEM micrographs showing colloidal Ag precipitates formed in fused silica by the implantation of $\mathrm{Ag}\left(1.8 \mathrm{MeV}, 6 \times 10^{16} \mathrm{~cm}^{-2}\right)$ ions at room temperature. Adapted with permission from Ann. Rev. Mater. Sci. 24 (1994) 125-158 (Buchal et al., 1994).

Implantation of these metal ions of moderate energy (typically up to $200 \mathrm{keV}$ ) and low doses $\left(\sim 10^{16} \mathrm{~cm}^{-2}\right)$ generally produces metallic nanoclusters of homogeneous sizes, while a high dose and a high temperature post implantation treatment produce nanoclusters of bigger sizes with higher dispersion. However, both the size and the size dispersion of the formed nanoclusters depend on the nature of implanted metal, their solubility and diffusion behavior in the embedding matrix. While Ag nanoclusters of relatively uniform sizes and narrow size distributions can be grown in silica matrix even for a high ion dose (Figure 5) 
without post-implantation thermal treatment, the same is not true for the $\mathrm{Au}$ and $\mathrm{Cu}$ nanoclusters in silica matrix (Figure 6). As can be seen from Figure 6, Au nanoparticles formed with similar implantation conditions and thermal treatments have a broad size distribution.

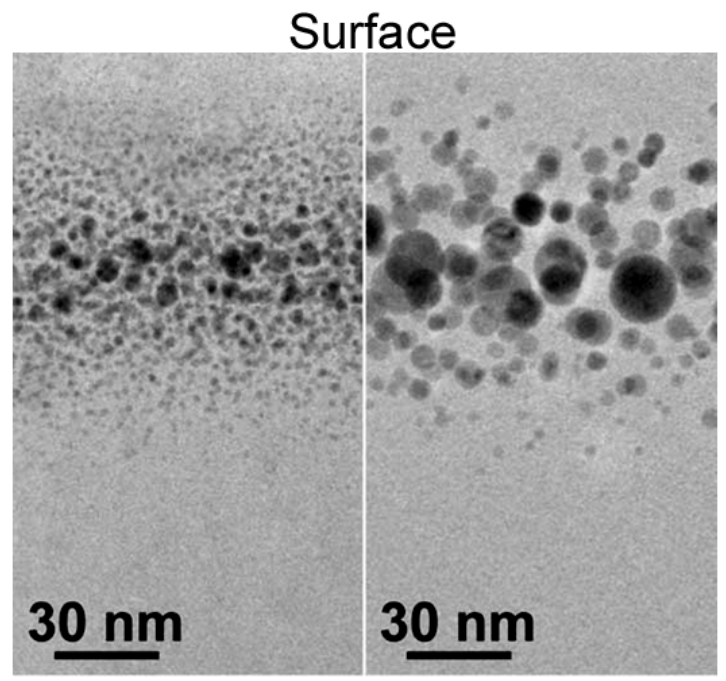

Fig. 6. Cross-sectional bright field TEM images of Au implanted $\left(190 \mathrm{keV}, 3 \times 10^{16} \mathrm{~cm}^{-2}\right)$ silica: a) before and b) after $3 \mathrm{~h}$ of thermal annealing at $900^{\circ} \mathrm{C}$, in air. Reproduced with permission from Nucl. Instrum. Meth. B 191 (2002) 323-332 (Mattei, 2002).

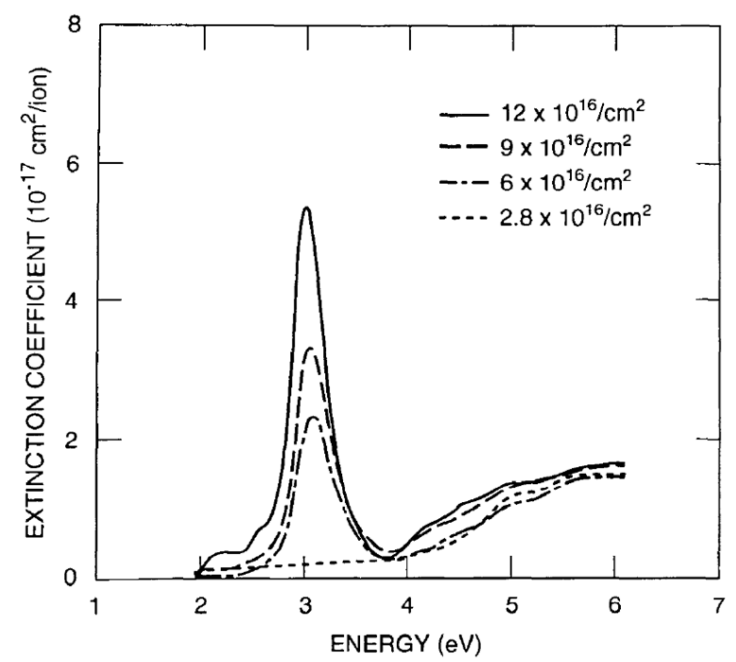

Fig. 7. Optical absorption spectra of $1.8 \mathrm{MeV}$ Ag implanted fused silica at room temperature prepared with different doses. Reproduced with permission from Ann. Rev. Mater. Sci. 24 (1994) 125-158 (Buchal et al., 1994). 
While a very low ion dose produces metal nanoclusters of extremely small sizes (typically below $1.0 \mathrm{~nm}$ ) that exhibit no SPR band in absorption spectra, on increasing the ion dose, the clusters grow and the intensity of the SPR extinction band increases (Figure 7). On the other hand, for a high energy of the implanted ions, the size of the formed metallic clusters can be big enough to reveal an SPR peak in the absorption spectra of the composites (Figure 8B). While a high energy implantation can place the metallic clusters at micrometer depth below the irradiated surface, a higher implantation dose can extend the cluster distribution towards the target surface (Figure 8A). Such a broadening of cluster distribution towards lower depths is due to the interaction of the incident ions with the already formed metallic clusters, which effectively reduces the projected range of the metal ions that impinge at a later stage.
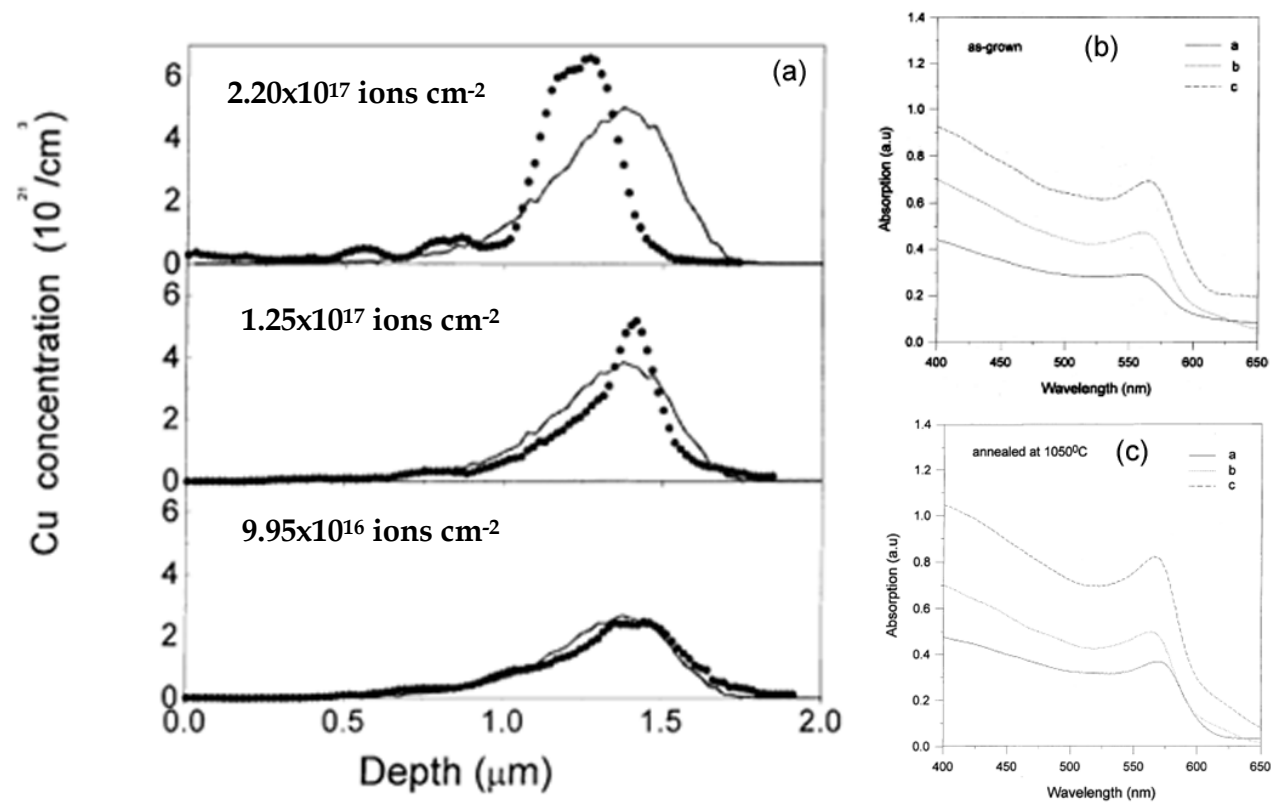

Fig. 8. a) The depth profiles of $\mathrm{Cu}$ concentration in silica matrix prepared with $2.0 \mathrm{MeV} \mathrm{Cu}$ ions of $9.95 \times 10^{16}, 1.25 \times 10^{17}$, and $2.20 \times 10^{17}$ ions $\mathrm{cm}^{-2}$ doses without post implantation treatment, estimated through RBS analysis. The continuous lines show the TRIM simulated results. Optical absorption spectra of the Cu implanted silica before (b) and after (c) thermal annealing at $1050^{\circ} \mathrm{C}$. Adapted with permission from J. Non-Cryst. Sol. 275 (2000) 65-71 (Pal et al., 2000).

Overall, incorporation of monometallic NPs in dielectric matrix through ion implantation has had a good success so far. At the present time, researchers can fabricate specific noble metal clusters of desired sizes and size distributions at precise depths inside most common dielectric matrices by controlling the implantation dose, energy and the conditions of post implantation treatment. However, from the application point of view the success has been limited. Though the SPR position in a nanocomposite could be 
modified by varying the nature of implanted metal ions (e.g. the typical SPR position of $\mathrm{Au}$ nanoclusters in $\mathrm{SiO}_{2}$ is at about $540 \mathrm{~nm}$, of $\mathrm{Ag}$ at about $420 \mathrm{~nm}$, and of $\mathrm{Cu}$ at about 560 $\mathrm{nm}$ ) and its intensity could be raised by increasing the implantation dose, it is not possible to tune the position of the SPR peak for a wider spectral range using monometallic nanoclusters. The fabricated monometallic plasmonic nanocomposites are suitable for the fabrication of nonlinear optical switches, effective waveguides, optical sensors, and devices covering a limited spectral range, but the limitation of spectral tunability of SPR peak position makes them unsuitable for most biological applications, such as medical diagnosis, immunoassay, and therapeutic treatments.

Therefore, researchers felt the need of fabricating plasmonic nanocomposites containing bimetallic nanoclusters to vary the SPR position of the composites in between the SPR positions of individual monometallic metal clusters, which we will discuss in the following section.

\subsection{Fabrication of nanocomposites containing alloy- and core-shell type bimetallic clusters}

Sequential ion implantation, where the ions of a particular metal are first implanted at a certain depth of the matrix and then the second type of metal ions are implanted at similar depths, has been utilized frequently to fabricate bimetallic nanocomposites. Depending on the conditions of implantation, the nature of metallic species and dielectric matrix, the process can lead to the formation of i) separated monometallic nanoclusters of individual metals, ii) alloy clusters, and iii) core-shell type bimetallic clusters. Formation of each of these clusters depends on their thermodynamic stability, and hence on the process of post-implantation thermal treatments along with the annealing atmosphere. Although the composition of alloy type clusters can be varied easily by sequential ion implantation of two elements in a matrix by adjusting their energy and doses to have maximum overlap between their implant-profiles and desired local relative concentrations, post implantation thermal treatments can frequently lead to (promote) separation of a component specie from the other or oxidation, instead of alloying. Formation of alloy type clusters also depends on the miscibility of the component elements, their chemical interaction with the matrix, and the creation of radiation induced defects, which influences the nucleation and growth of the nanoclusters.

As the criterion of bulk miscibility for two elements is not very stringent in the case of nanocrystals due to their high specific surface area (surface area/volume ratio) and characteristics closer to that of a molecule than to those of a massive (bulk) system (Yasuda \& Mori, 1994), alloy type nanoclusters of several metal pairs like $\mathrm{Au}-\mathrm{Cu}, \mathrm{Au}-\mathrm{Ag}, \mathrm{Pd}-\mathrm{Ag}$, and Pd-Cu, have been successfully fabricated (Gonella et al., 1999; Battaglin et al., 2000, 2001a) through sequential ion implantation. The SPR position in such noble metal alloy clusters remains in between those of pure elements, depending on the complex interplay between the modified free electrons and interband absorptions. As can be seen from Figure 9, the measured absorption spectra of pure $\mathrm{Au}, \mathrm{Ag}$ and $\mathrm{Au}_{0.4} \mathrm{Ag}_{0.6}$ alloy clusters of about $3 \mathrm{~nm}$ size in silica matrix reported by Mattei and co-workers (Mattei, 2002) agree well with the simulated extinction spectra of the NPs of similar compositions reported by Kreibig \& Vollmer (Kreibig \& Vollmer, 1995). 


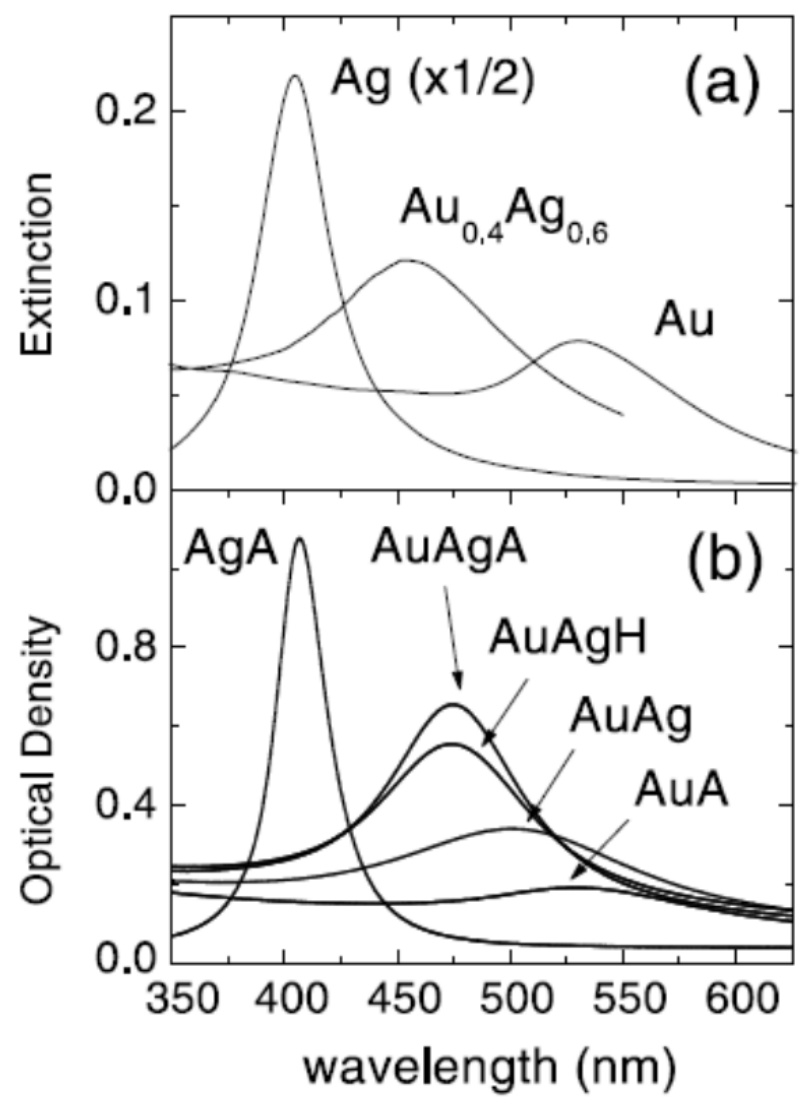

Fig. 9. Comparison between Mie-theory based calculated extinction spectra of $3 \mathrm{~nm}$ clusters of $\mathrm{Au}, \mathrm{Ag}$, and $\mathrm{Au}_{0.4} \mathrm{Ag}_{0.6}$ alloy in silica (9a) with the experimental absorption spectra of similar clusters prepared by ion implantation (9b). The notations " $\mathrm{A}$ " and " $\mathrm{H}$ " at the end of sample names indicate the samples were annealed in air and hydrogen atmosphere, respectively. Reproduced with permission from Nucl. Instrum. Meth. B 191 (2002) 323332 (Mattei, 2002).

Using sequential implantation technique, Mazzoldi and collaborators were able to fabricate alloy nanoclusters of different compositions in fused silica glass at room temperature using $190 \mathrm{keV}$ gold and $90 \mathrm{keV} \mathrm{Cu}$ ions (Gonella et al., 1999). The alloy clusters of compositions close to their nominal values were formed in the silica matrix even without any postimplantation thermal treatment (Figure 10). However, $\mathrm{Cu}$ migrates towards the particle surface during thermal treatment and a structural reordering of the alloy occurs. The effect was more prominent when the implanted samples were annealed in air, and $\mathrm{Cu}$ migrated to the surface gets oxidized, causing a phase separation ( $\mathrm{Au}$ core and $\mathrm{Cu}_{2} \mathrm{O}$ shell). A complete separation of $\mathrm{Cu}$ from the alloy cluster and formation of $\mathrm{CuO}$ shell around the $\mathrm{Au}$ core could be obtained after $5 \mathrm{~h}$ of thermal annealing in air (Battaglin et al., 2001b). The process could be reversed by annealing the sample again in a reducing atmosphere. It must be noted 
that for the thermal treatment of metal ion implanted composites we frequently use the value of the bulk melting point temperature, even though this quantity is substantially lower for a metallic cluster (either elemental or bimetallic), due to thermodynamic size effect (Buffat \& Borel, 1976). Thermal annealing of a sequentially implanted sample helps to migrate one component elemental species towards the small clusters of the other element through diffusion, enhancing their size and improving their stoichiometry. In fact, the probability of formation of homogeneous alloy clusters in sequential implantation process strongly depends on the solubility of the second elemental specie in the nanoclusters of the first element. To increase the solubility and helping the structural rearrangement of metal ions, sometimes it is useful to perform the implantation of the second element at elevated target (substrate) temperatures.
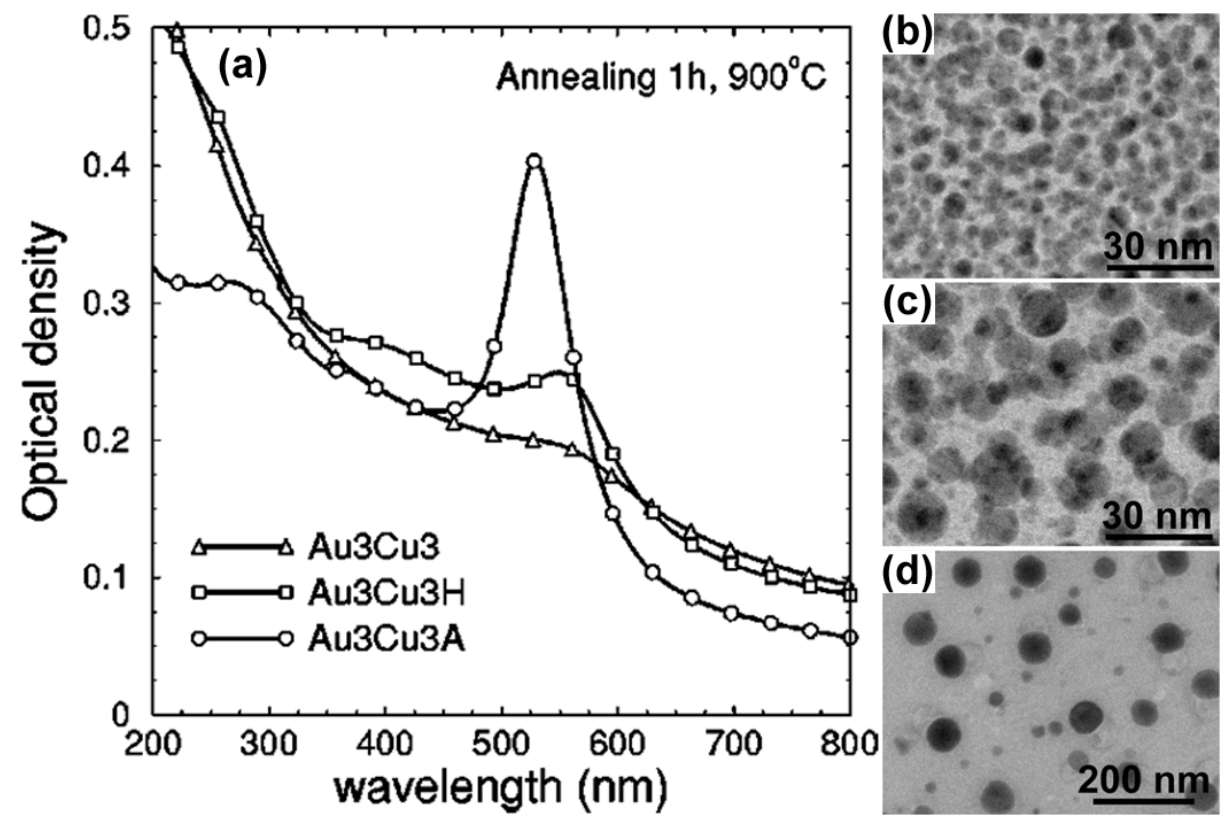

Fig. 10. (a) Optical absorption spectra of $\mathrm{Au}_{3} \mathrm{Cu}_{3}$ (as-implanted), $\mathrm{Au}_{3} \mathrm{Cu}_{3} \mathrm{H}$, and $\mathrm{Au}_{3} \mathrm{Cu}_{3} \mathrm{~A}$ (annealed at $900{ }^{\circ} \mathrm{C}$ for $1 \mathrm{~h}$ in $\mathrm{H}_{2}$-Ar and air, respectively) samples. The bright-field TEM planer views of the corresponding samples are presented as (b), (c), and (d), respectively, at right. Reproduced with permission from Appl. Phys. Lett. 75 (1999) 55-57 (Gonella et al., 1999).

Utilizing the above mentioned strategy, Kluth and coworkers (Kluth et al., 2006) could fabricate core-shell type $\mathrm{Co}-\mathrm{Au}$ nanoclusters of about $5.3 \mathrm{~nm}$ diameter in $\mathrm{SiO}_{2}$ matrix. Utilization of elevated target temperature $\left(400^{\circ} \mathrm{C}\right.$ in the present case) during second metal (Co in this work) implantation helped to avoid the post-implanted thermal annealing process for the formation of bimetallic clusters. However, for the formation of Au clusters of uniform size before Co implantation, they used a thermal annealing treatment of the $\mathrm{Au}$ implanted sample at $1000{ }^{\circ} \mathrm{C}$ for one hour, in air. We can see the formation of uniform nanoparticles with Co core and Au shell (Figure 11) in their samples. As has been mentioned earlier, the formation of core-shell type bimetallic clusters depends strongly on the 
segregation of the component metals controlled by the minimization of surface free energy, resulting a phase separation as has been demonstrated theoretically for Co-Au (Johannessen et al., 2005), Au-Pt (Esparza et al., 2005), Au-Pd (Liu et al., 2005, 2006), Au-Cu (Ascencio et al., 2006) and many other systems.
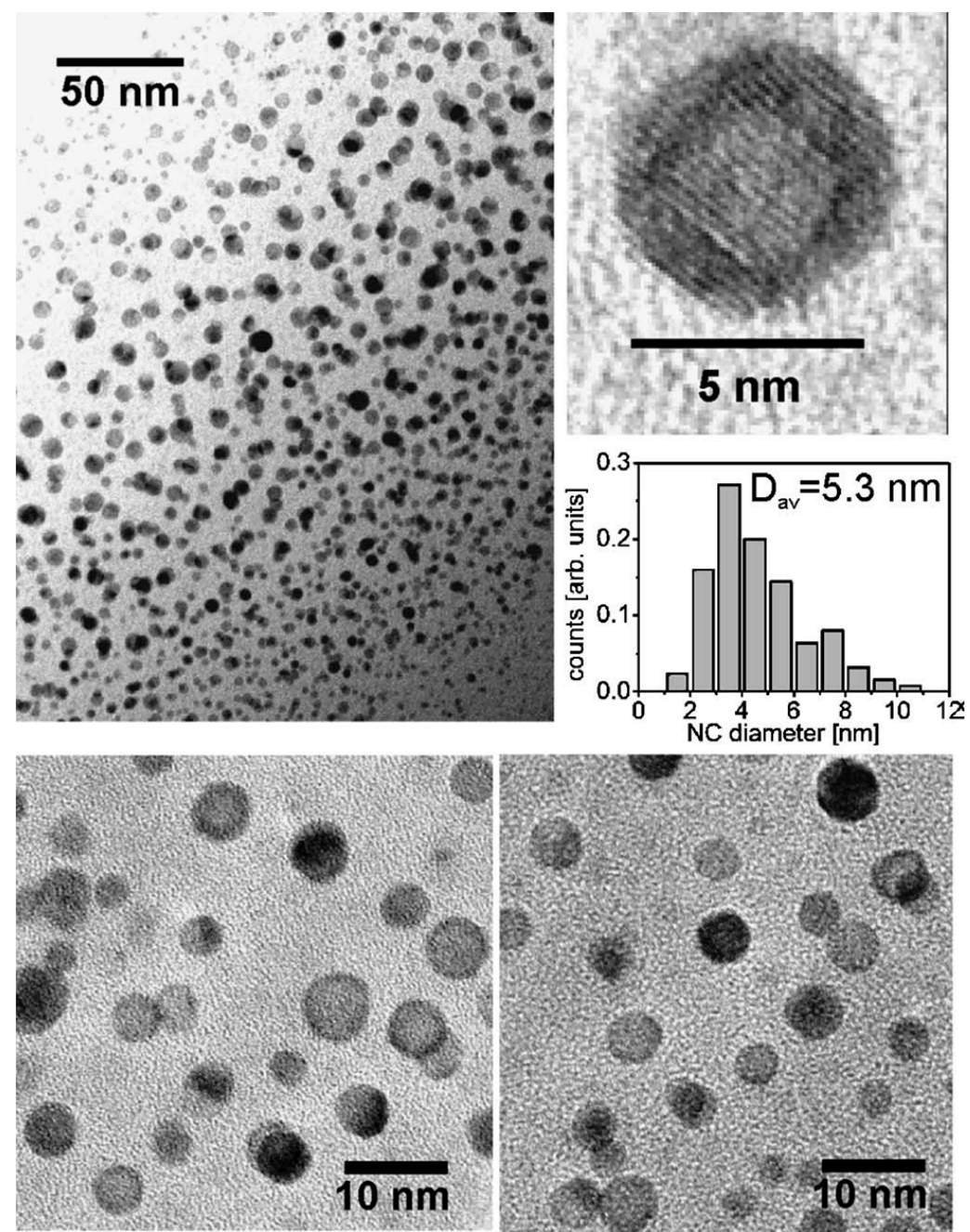

Fig. 11. Cross-sectional TEM images and size distribution of Co-Au nanoclusters as well as monometallic nanoclusters formed by sequential implantation. The high resolution TEM image of the core-shell cluster reveals a significant bending of the lattice fringes due to interfacial strain (lattice mismatch). Reproduced with permission from Appl. Phys. Lett. 89 (2006) 153118 (Kluth et al., 2006).

Formation of Au-Ag core-shell nanoclusters in silica matrix through sequential implantation and subsequent thermal annealing (in air) has been demonstrated by Peña and 
coworkers (Peña et al., 2009). Considering the miscibility and segregation behavior of the two metals, they first implanted $1.8 \mathrm{MeV} \mathrm{Ag}^{+}$ions at a $5.0 \times 10^{16}$ ions $\mathrm{cm}^{-2}$ dose (fluence) to place most of them at about $1.0 \mu \mathrm{m}$ depth below the target surface (Figure 12). Then, the $\mathrm{Au}^{+}$ ions of higher energy $(3.7 \mathrm{MeV})$ were implanted at a relative higher dose $\left(6.7 \times 10^{16}\right.$ ion $\left.\mathrm{cm}^{-2}\right)$ to place them at greater depth (about $1.1 \mu \mathrm{m}$ ) keeping a good portion of the implantation profiles overlapped. However, it has been observed that during the implantation of Au, preimplanted Ag segregates towards the sample surface (distribution maximum moves to $\sim 0.87 \mu \mathrm{m}$ depth). On thermal annealing at $900^{\circ} \mathrm{C}$ for $1 \mathrm{~h}$ in air, the co-implanted samples produced core-shell type bimetallic nanoclusters with Au core and Ag shell. The formation of both the monometallic nanoclusters (embedded in silica matrix) before thermal treatment and bimetallic nanoclusters (after thermal treatment) could be verified through the experimental optical absorption spectra in comparison with the Mie theory based simulated spectra of similar structures (Figure 13).

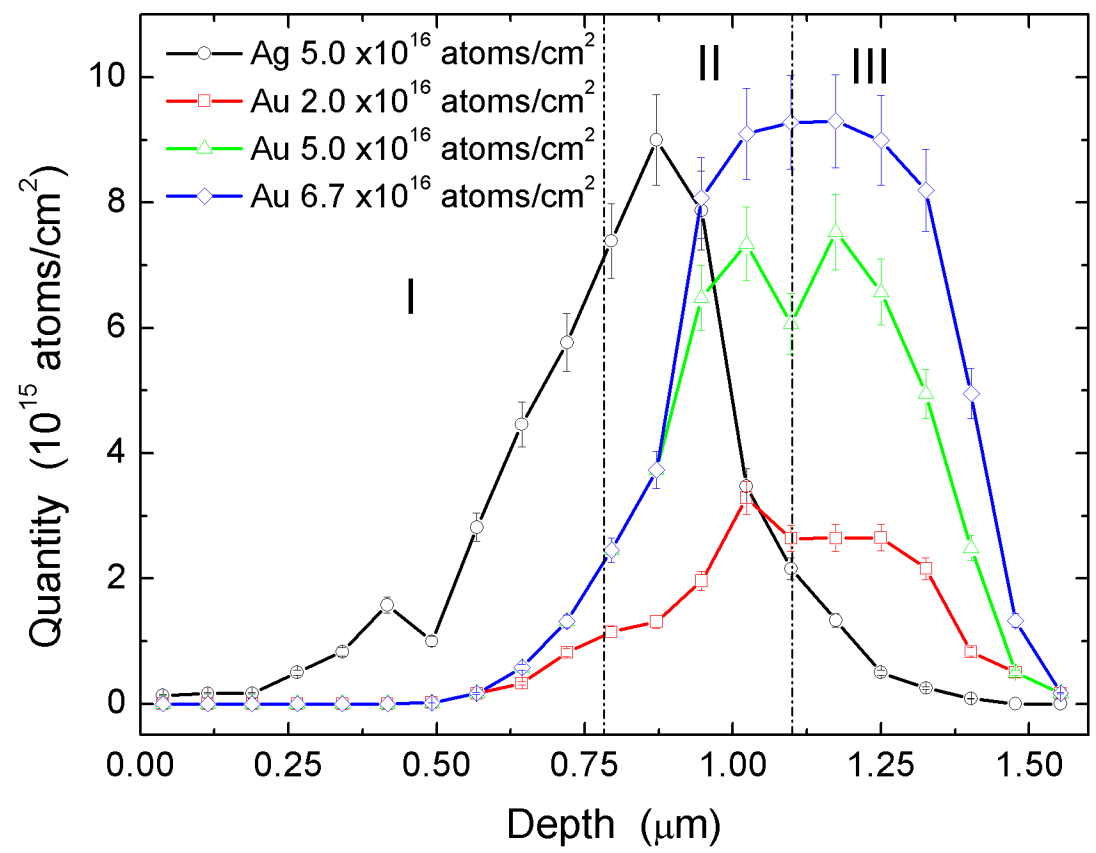

Fig. 12. Depth profiles of $\mathrm{Au}$ and Ag distribution for the silica samples sequentially implanted with $\mathrm{Ag}(1.8 \mathrm{MeV})$ and $\mathrm{Au}(3.5 \mathrm{MeV})$ ions, obtained from the fitting of the corresponding RBS spectra. Reproduced with permission from J. Phys. Chem. C 113 (2009) 2296-2300 (Peña et al., 2009).

Though it was not possible to differentiate the core and shell regions from their HRTEM images, due to very similar lattice parameters of Au and Ag (4.078 $\AA$ for Au, JCPDS 4-0784; $4.077 \AA$ for Ag, JCPDS 87-0720), the formation of core-shell structures could be demonstrated using high angle annular dark field (DAADF) images of the nanoclusters (Figure 14). 


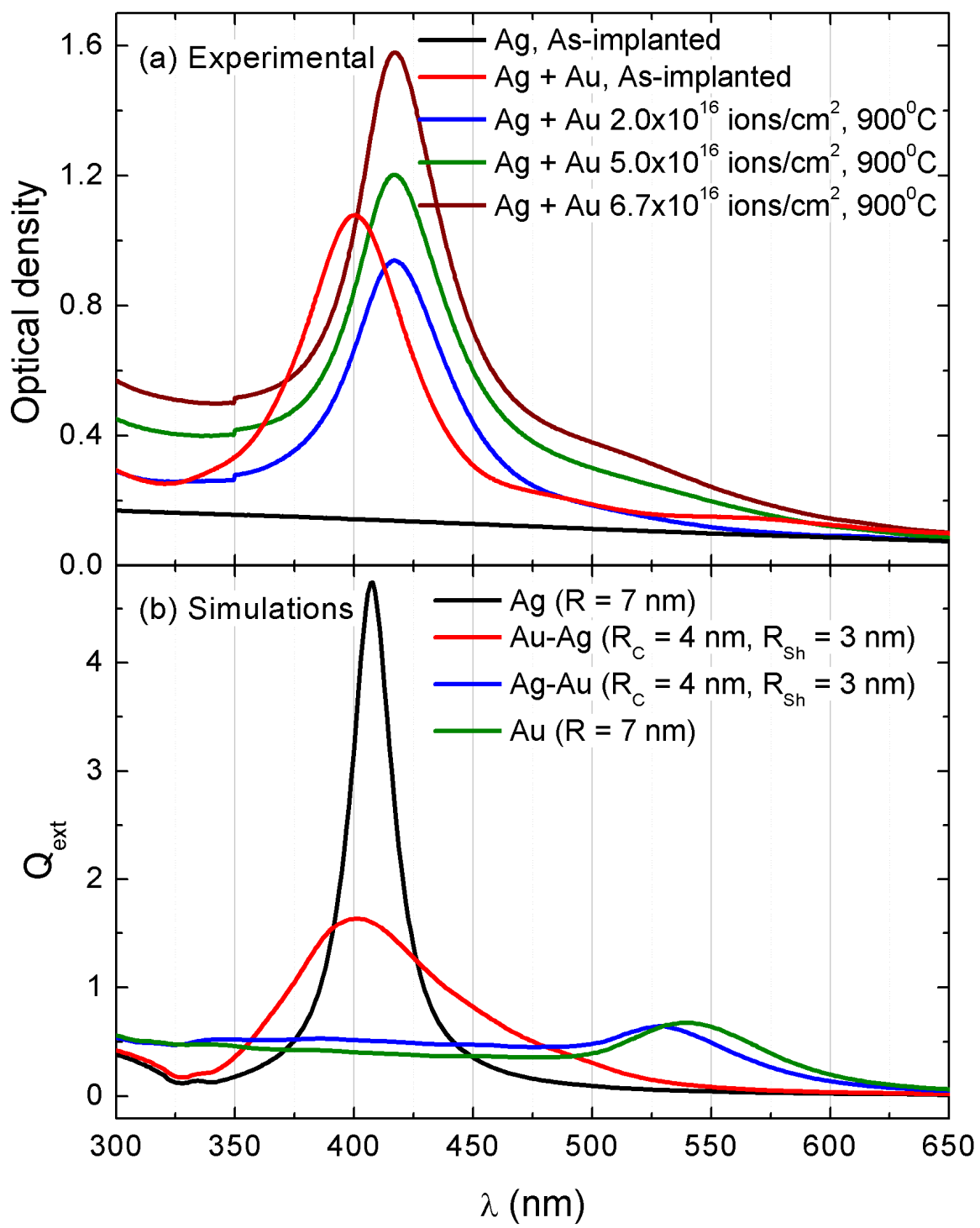

Fig. 13. Experimental optical extinction spectra for the samples implanted with $5 \times 10^{16}$ ions $\mathrm{cm}^{-2}$ of $\mathrm{Ag}$ at $1.8 \mathrm{MeV}$ and coimplanted with different fluences of $\mathrm{Au}$ at $3.5 \mathrm{MeV}$, before and after thermal annealing in air (a), and simulated (Mie theory) extinction spectra for some possible configurations in silica matrix (b). Au-Ag represents Au core-Ag shell, whereas AgAu means the opposite. Reproduced with permission from J. Phys. Chem. C 113 (2009) 22962300 (Peña et al., 2009).

Indeed, the ion implantation process can produce both, alloy and core-shell type bimetallic nanoclusters in silica and other dielectric matrices by adequate manipulation of implantation 
parameters and proper post-implantation treatments. However, apart from producing monometallic and bimetallic nanoclusters of common types, ion implantation can produce several special metallic structures and aggregates, which we will discuss in the next section.
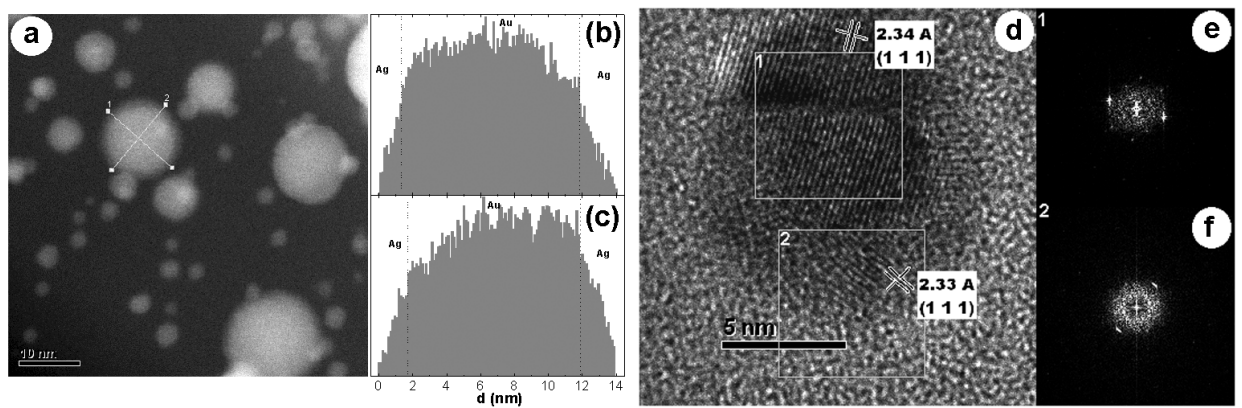

Fig. 14. Typical HAADF micrograph of the sample co-implanted with $5 \times 10^{16}$ ions cm $\mathrm{cm}^{-2}$ of $\mathrm{Ag}$ $(1.8 \mathrm{MeV})$ and $5 \times 10^{16}$ ions $\mathrm{cm}^{-2}$ of $\mathrm{Au}(3.5 \mathrm{MeV})$ after thermal annealing at $900{ }^{\circ} \mathrm{C}$ (a) along with the intensity profiles for the selected particle (b) and (c). Typical HRTEM micrograph of a core-shell structure of about $12 \mathrm{~nm}$ diameter and the fast Fourier transforms (FFTs) of core (e) and shell (f) regions. Adapted with permission from J. Phys. Chem. C 113 (2009) 2296-2300 (Peña et al., 2009).

\subsection{Fabrication of nanocomposites containing unusual metallic nanostructures}

The anisotropic plastic deformation process of amorphous materials under $\mathrm{MeV}$ ion irradiation has been reported by Klaumünzer and Schumacher as early as 1983 (Klaumünzer \& Schumacher, 1983). The process can be understood by means of a visco-elastic model, in which the thermal expansion of the cylindrically-shaped high temperature ion track region causes shear stresses that relax by viscous flow, with the viscous strains subsequently frozen in upon rapid cooling of the ion track region (Trinkaus \& Ryazanov, 1995; van Dillen et al., 2005). The deformation is induced by the electron energy loss, and thus occurs mostly with ions in the $\mathrm{MeV}$ energy range.
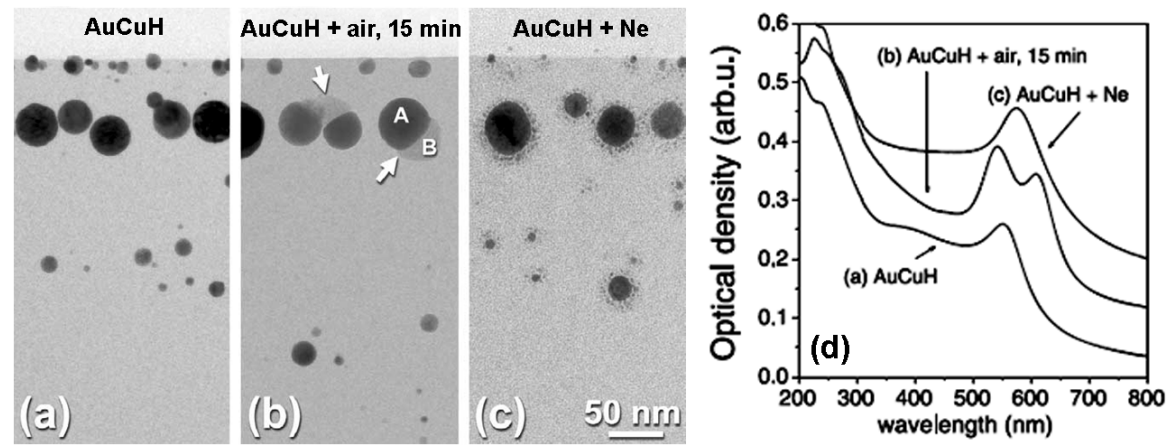

Fig. 15. Bright-field TEM cross-sectional micrographs of the AuCuH (annealed in $\mathrm{H}_{2}(4.0 \%)-\mathrm{N}_{2}$ atmosphere at $900^{\circ} \mathrm{C}, 1 \mathrm{~h}$ ) before (a), after a thermal annealing in air at $900{ }^{\circ} \mathrm{C}$ for $15 \mathrm{~min}(\mathrm{~b})$ and after irradiation at room temperature with $190 \mathrm{keV} \mathrm{Ne}$ ions, at a dose of $1.0 \times 10^{17}$ ions $\mathrm{cm}^{-2}$ (c). Adapted with permission from J. Non-Cryst. Sol. 322 (2003) 17-21 (Mattei et al., 2003a). 
Utilizing the above mentioned concept, ion implantation technique has been utilized for the fabrication of several unusual nanostructures either inside dielectric matrices or in other dielectric-metal combinations with distinct plasmonic behaviors. Though all of these nanostructures do not fall into the class of commonly known nanocomposites (where nanoparticles of one material are embedded/dispersed into another matrix material), as they are in combination with at least one material apart from the metal in question, we can call them as composite nanostructures. For example, Mattei and co-workers (Mattei et al., 2003a, 2005) could disintegrate alloy clusters like Au-Cu and Au-Ag embedded in silica matrix by high energy $\mathrm{Ne}, \mathrm{He}$ and $\mathrm{Kr}$ ions to form Au-rich satellite clusters around the initial bimetallic clusters (Figures 15 \& 16).

While the optical absorption spectrum of the co-implanted (190 keV Au and $90 \mathrm{keV} \mathrm{Cu}$, $3.0 \times 10^{16}$ ions $\mathrm{cm}^{-2}$ ) AuCu sample after annealing in inert atmosphere revealed SPR peak of $\mathrm{AuCu}$ alloy particles (550 nm, curve (a) of the Figure 15), after irradiation of $190 \mathrm{keV}$ Ne ions (1.0x1017 ions $\mathrm{cm}^{-2}$ ) the SPR peak shifts to $575 \mathrm{~nm}$, which correspond to the SPR band of the main particle along with the satellite ones (aggregate). Similar phenomenon occurred for the AuAg nanoclusters embedded in silica matrix. It has been observed that in both cases, mainly the Au segregates out of the main bimetallic cluster to form Au-rich satellite clusters of smaller sizes. The size of the satellite clusters depends on the atomic mass of the irradiating ions. Higher atomic mass of the irradiating ions produces satellite clusters of bigger sizes (Figure 16). However, the phenomenon of disintegration of the preformed noble metal clusters in dielectric matrix occurs when the atomic mass of the irradiating ions is lower than the atomic mass of the embedded metal nanoclusters. The process was tentatively related to the nuclear component of the energy released to the system during irradiation with different ions.
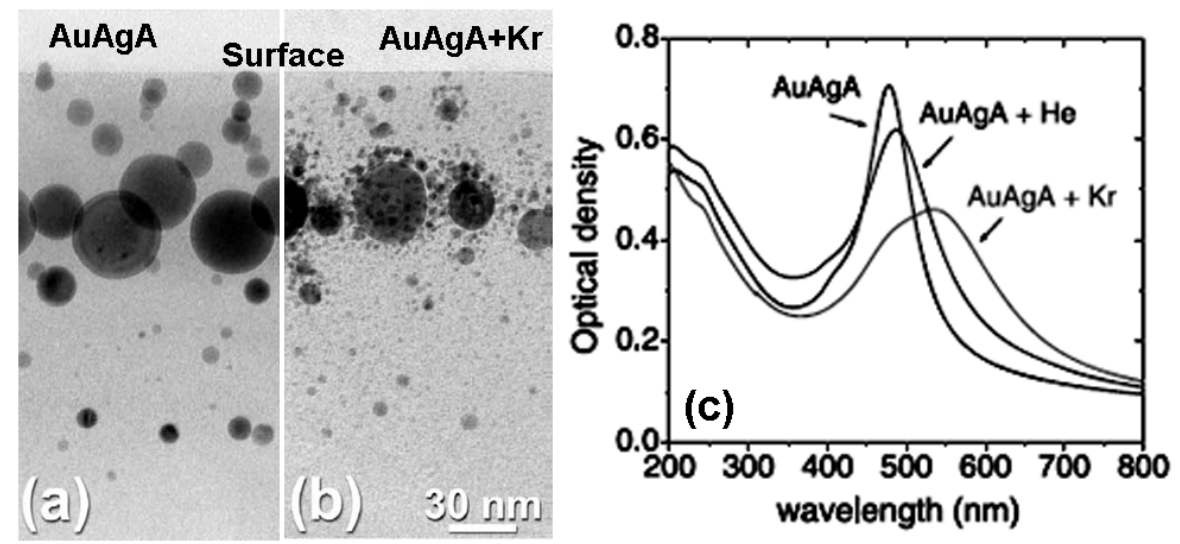

Fig. 16. Bright-field TEM cross-sectional micrographs of the sample AuAgA (annealed in air atmosphere at $800^{\circ} \mathrm{C}, 1 \mathrm{~h}$ ) before (a) and after irradiation at room temperature with $380 \mathrm{keV}$ $\mathrm{Kr}$ ions at a dose of 2.0x1016 ions $\mathrm{cm}^{-2}$ (b) (Mattei et al., 2003a). Adapted with permission from J. Non-Cryst. Sol. 322 (2003) 17-21 (Mattei et al., 2003a).

On the other hand, irradiation by high energy ions of higher atomic mass (with respect to the implanted metals in a dielectric matrix) generates very different phenomena. Generally, 
when an embedded metallic nanocluster is irradiated by heavier ions of higher energy (in comparison to the energy of implantation of the metal clusters), the preformed nanocluster can grow in bigger size or get deformed. For the low dose/fluence of irradiation, the preformed metallic nanoclusters grow in size maintaining their initial shape. However, an increased dose of irradiation generates deformation of the nanoclusters. In fact, several researchers have reported this deformation process for the noble metal nanoclusters embedded in amorphous dielectric matrices. While D'Orléans and co-workers (D'Orléans et al., 2003) could observe this effect for the preformed Co nanoclusters embedded in silica matrix upon irradiating them by $200 \mathrm{MeV}$ 127I ions, Awazu and co-workers (Awazu et al., 2009) could observe this effect for the pre-implanted gold and silver nanoclusters embedded in silica matrix (Figure 17).

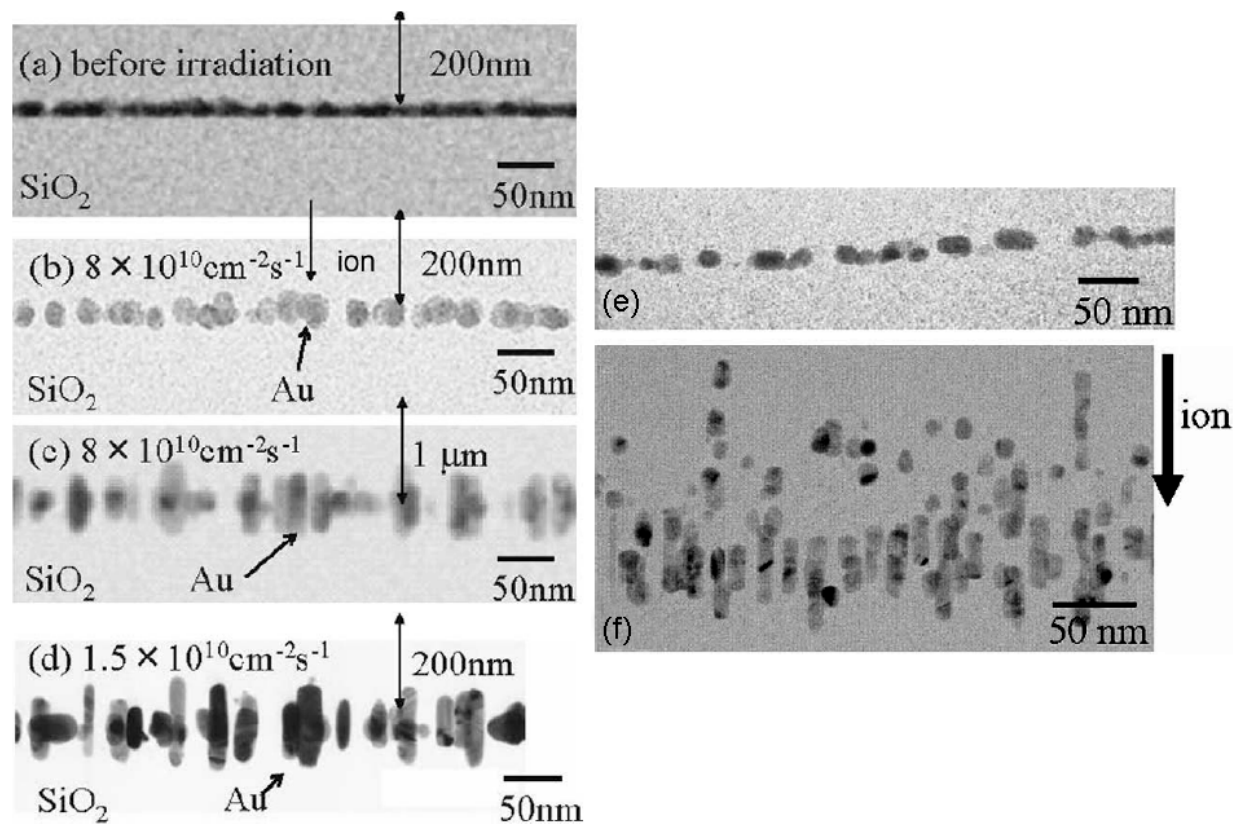

Fig. 17. Cross-sectional TEM image of $\mathrm{Au}$ (left) and Ag (right) nanoparticles embedded in $\mathrm{SiO}_{2}$ before and after irradiation with $110 \mathrm{MeV} \mathrm{Br}{ }^{10+}$ ions at different doses. The $\mathrm{Ag}$ nanoparticles were irradiated with $1.0 \times 10^{14}$ ions $\mathrm{cm}^{-2}$ dose. Adapted with permission from Nucl. Instrum. Meth. B 267 (2009) 941-943 (Awazu et al., 2009).

$\mathrm{Ag}$ and $\mathrm{Au}$ nanoclusters could also be deformed on irradiating them by high energy Si ions to form elongated or rod shaped aligned nanoclusters in silica matrix (Rodríguez-Iglesias et al., 2010a; b). As we can see from Figure 18, the elongated nanoclusters are well aligned, and generate SPR absorption bands corresponding to longitudinal and transversal vibrational modes of prolate nanoclusters on oblique incidence. Indeed, the metallic clusters get deformed upon irradiation of high energy heavy ions along the direction of incident ions; i.e. they get elongated in this direction. On the contrary, the deformation or expansion of nonmetallic or dielectric clusters occurs in the perpendicular direction of the irradiating ion beams. 

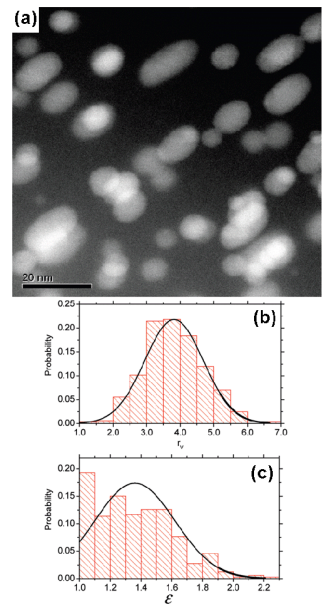

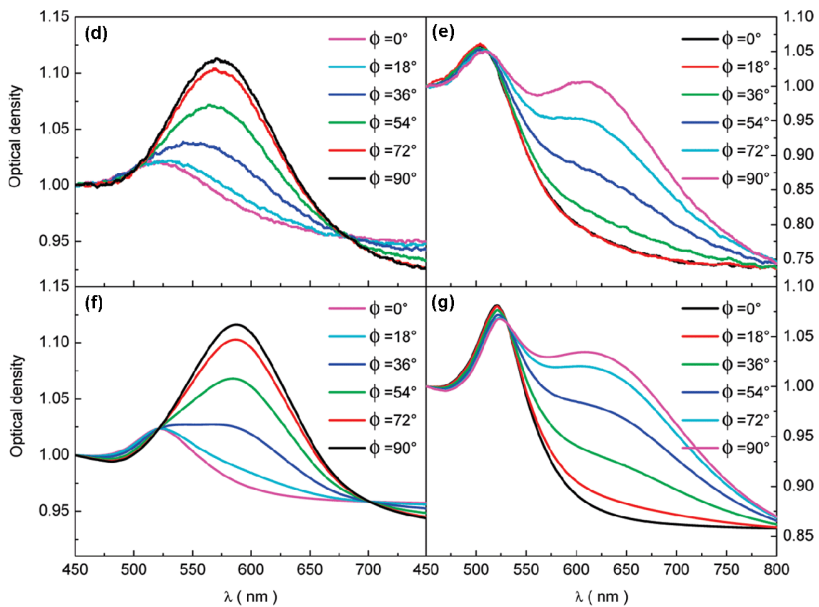

Fig. 18. Experimental optical extinction spectra of elongated Au nanoclusters (a)-(c), measured for the light incident at (d) $90^{\circ}$, and (e) $29^{\circ}$ and polarization angles varying between $0^{\circ}$ (p-polarized) and $90^{\circ}$ (s-polarized). Corresponding simulated spectra (Mie theory) are presented in (f), and (g), respectively. All the spectra were normalized to 1 at the $450 \mathrm{~nm}$ wavelength for better visualization. Adapted with permission from J. Phys. Chem. C 114 (2010) 746-751 (Rodríguez-Iglesias et al., 2010b).
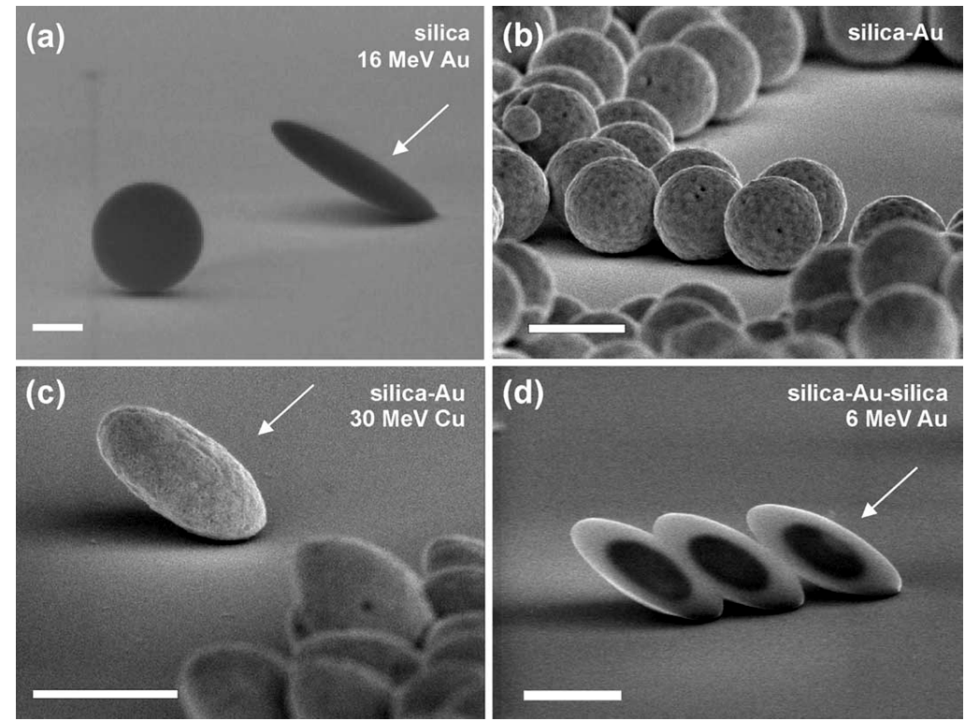

Fig. 19. Scanning electron microscopy images of (a) silica colloid (1.0 $\mu \mathrm{m}$ diameter) before (left) and after (right) $16 \mathrm{MeV}$ Au irradiation (1.1×1015 ions $\left.\mathrm{cm}^{-2}\right)$; (b) silica-Au core-shell colloid $\left(\mathrm{d}_{\mathrm{SiO} 2}=438 \mathrm{~nm}, \mathrm{t}_{\mathrm{Au}}=46 \mathrm{~nm}\right)$; (c) same as (b), after $30 \mathrm{MeV} \mathrm{Cu}$ irradiation (5.0x1014 ions cm-2); (d) silica-Au-silica core-shell-shell colloid $\left(\mathrm{d}_{\mathrm{SiO} 2}=300 \mathrm{~nm}, \mathrm{t}_{\mathrm{Au}}=25 \mathrm{~nm}, \mathrm{t}_{\mathrm{SiO} 2}=133 \mathrm{~nm}\right)$ after 6 $\mathrm{MeV}$ Au irradiation $\left(6.5 \times 10^{14}\right.$ ions $\left.\mathrm{cm}^{-2}\right)$. Scale bars represent $500 \mathrm{~nm}$. Reproduced with permission from Nucl. Instrum. Meth. B 242 (2006) 523-529 (Penninkhof et al., 2006). 
Utilizing this deformation behavior of metal and dielectric nanoparticles, Pennikhof and coworkers (Penninkhof et al., 2006) could produce colloidal prolate core-shell type $\mathrm{Au}-\mathrm{SiO}_{2}$ and reverse nanoparticles as big as $1 \mu \mathrm{m}$ in size (Figure 19) by irradiating high energy Au or $\mathrm{Cu}$ ions. As the ion irradiation induced deformation is more prominent for a dielectric like $\mathrm{SiO}_{2}$ than a metal like $\mathrm{Au}$, the extent of deformation of the $\mathrm{SiO}_{2}$-core Au-shell particles is not as drastic as of Au-core $\mathrm{SiO}_{2}$-shell particles. In fact, the presence of a thin layer (shell) of metal imposes a mechanical constrain on the deforming silica core, reducing the net deformation compared to that of pure silica (Penninkhof et al., 2006).

Optical characteristics of all the above plasmonic structures, which we defined as 'special structures' are quite different from that of conventional nanocomposites where the shape of incorporated/embedded noble metal nanoclusters remains in its most stable or spherical form. As the technological application of plasmon-based nanocomposites remains on the ability of manipulating their optical behavior, which is possible mainly by controlling the size, shape and other geometrical parameters, rather than just changing their composition. Ion implantation technique has demonstrated its great potential for their fabrication and manipulations.

\section{Prospects of ion-implantation for the fabrication of plasmonic nanocomposites}

Significant advances have been made in the last few decades on the fabrication of noble metal plasmonic nanocomposites through ion implantation. By controlling the implantation parameters and post implantation annealing, noble metal nanocomposites with embedded elemental, alloy and core-shell type NPs could be produced with moderate control over the NP size, size distribution, composition and location in the matrix. The significant advantage of ion implantation technique is that the treated surface is an integral part of the sample and consequently does not suffer from possible adhesion problems associated with coatings. Therefore, the implanted structures remain as the integral parts of an optical device. The moderate heating associated with the process virtually eliminates any risks of distortion or oxidation effects. On the other hand, ion implantation produces no macroscopic change in the workpiece. From the point of view of applications, though several plasmonic nanocomposites with embedded noble metal clusters of tailored compositions and even of core-shell geometries could be fabricated extending their SPR peak position to a broader spectral range (in comparison with monometallic nanocomposites), tuning the relative thickness of the core and shell layer has not been sufficiently demonstrated. As has been shown recently (Peña-Rodríguez \& Pal, 2010, 2011a; b; Peña-Rodríguez et al., 2011a; b), application potential of plasmonic nanostructures depends on their enhanced SPR extinction, along with a precise control over its peak position. For this purpose, it is possible that in the near future we will need to fabricate multi-layer metallic nanoclusters with precise control over the thickness of each layer. Though the modern ion implanters are capable of introducing virtually any element in a solid matrix with a wide variation of energy and implantation dose, there has been no attempt to fabricate nanocomposites with trimetallic nanoclusters incorporated into dielectric matrix. On the other hand, fewer efforts have been devoted to control the shell-thickness in a core-shell type nanocluster or the fabrication of multilayer metallic nanoclusters. However, very recently this technique has been utilized for the fabrication of unusual composite nanostructures with distinct 
plasmonic behaviors, which are highly attractive for several applications from optical sensing to biological treatments. Considering the current interest on plasmonic nanostructures and nanocomposites and the demonstrated potential of available commercial ion implanters, utilization of this technique for fabricating new exotic nanostructures in the near future is very much expected.

\section{Acknowledgments}

The authors extend their apology to the several other authors who have contributed significantly in this field, but were not cited due to limited space of this review. The work was supported by CONACyT, Mexico (Grant \# 151767) and VIEP-BUAP (Grant \# VIEP/EXC/2011). OPR thanks CONACyT, Mexico for extending a postdoctoral fellowship.

\section{References}

Aaron, H. B., Fainstein, D. \& Kotler, G. R. (1970). Diffusion-limited phase transformations: A comparison and critical evaluation of the mathematical approximations. J. Appl. Phys. Vol.41, No.11, pp.4404-4410, ISSN 0021-8979.

Agulló-López, F., Catlow, C. R. A. \& Townsend, P. D. (1988). Point defects in materials. San Diego, CA, USA: Academic Press., ISBN 0120445107.

Alivisatos, P. (2004). The use of nanocrystals in biological detection. Nat. Biotechnol. Vol.22, No.1, pp.47-52, ISSN 1087-0156.

Allain, L. R. \& Vo-Dinh, T. (2002). Surface-enhanced Raman scattering detection of the breast cancer susceptibility gene BRCA1 using a silver-coated microarray platform. Anal. Chim. Acta Vol.469, No.1, pp.149-154, ISSN 0003-2670.

Arai, N., Tsuji, H., Ueno, K., Matsumoto, T., Gotoh, N., Aadachi, K., Kotaki, H., Gotoh, Y. \& Ishikawa, J. (2006). Formation of silver nanoparticles aligned near the bottom of $\mathrm{SiO}_{2}$ film on silicon substrate by negative-ion implantation and post-annealing. Nucl. Instrum. Meth. B Vol.242, No.1-2, pp.217-220, ISSN 0168-583X.

Arnold, G. W. \& Borders, J. A. (1977). Aggregation and migration of ion-implanted silver in lithia-alumina-silica glass. J. Appl. Phys. Vol.48, No.4, pp.1488-1496, ISSN 0021-8979.

Ascencio, J. A., Liu, H. B., Pal, U., Medina, A. \& Wang, Z. L. (2006). Transmission electron microscopy and theoretical analysis of $\mathrm{AuCu}$ nanoparticles: Atomic distribution and dynamic behavior. Microsc. Res. Tech. Vol.69, No.7, pp.522-530, ISSN 1097-0029.

Atwater, H. A. \& Polman, A. (2010). Plasmonics for improved photovoltaic devices. Nat. Mater. Vol.9, No.3, pp.205-213, ISSN 1476-1122.

Awazu, K., Wang, X., Fujimaki, M., Tominaga, J., Fujii, S., Aiba, H., Ohki, Y. \& Komatsubara, T. (2009). Mechanism of elongation of gold or silver nanoparticles in silica by irradiation with swift heavy ions. Nucl. Instrum. Meth. B Vol.267, No.6, pp.941-943, ISSN 0168-583X.

Ballesteros, J. M., Serna, R., Solís, J., Afonso, C. N., Petford-Long, A. K., Osborne, D. H. \& Haglund, R. F. (1997). Pulsed laser deposition of $\mathrm{Cu}: \mathrm{Al}_{2} \mathrm{O}_{3}$ nanocrystal thin films with high third-order optical susceptibility. Appl. Phys. Lett. Vol.71, No.17, pp.2445, ISSN 0003-6951.

Bamford, C. R. (1977). Colour generation and control in glass. 1. ed. Amsterdam: Elsevier Science Ltd., ISBN 0444416145. 
Bandourko, V., Umeda, N., Plaksin, O. \& Kishimoto, N. (2005). Heavy-ion-induced luminescence of amorphous $\mathrm{SiO}_{2}$ during nanoparticle formation. Nucl. Instrum. Meth. B Vol.230, No.1-4, pp.471-475, ISSN 0168-583X.

Barreca, D., Gasparotto, A., Tondello, E., Bruno, G. \& Losurdo, M. (2004). Influence of process parameters on the morphology of $\mathrm{Au} / \mathrm{SiO}_{2}$ nanocomposites synthesized by radio-frequency sputtering. J. Appl. Phys. Vol.96, No.3, pp.1655-1665, ISSN 00218979 .

Battaglin, G., Catalano, M., Cattaruzza, E., D’Acapito, F., De Julian Fernandez, C., De Marchi, G., Gonella, F., Mattei, G., Maurizio, C., Mazzoldi, P., Miotello, A. \& Sada, C. (2001a). Influence of annealing atmosphere on metal and metal alloy nanoclusters produced by ion implantation in silica. Nucl. Instrum. Meth. B Vol.178, No.1-4, pp.176-179, ISSN 0168-583X.

Battaglin, G., Cattaruzza, E., Gonella, F., Mattei, G., Mazzoldi, P., Sada, C. \& Zhang, X. (2000). Formation of metal-alloy nanoclusters in silica by ion implantation and annealing in selected atmosphere. Nucl. Instrum. Meth. B Vol.166-167, No.0, pp.857863, ISSN 0168-583X.

Battaglin, G., Cattaruzza, E., de Julian Fernandez, C., De Marchi, G., Gonella, F., Mattei, G., Maurizio, C., Mazzoldi, P., Miotello, A., Sada, C. \& D'Acapito, F. (2001b). Influence of post-implantation thermal and laser annealing on the stability of metal-alloy nanoclusters in silica. Nucl. Instrum. Meth. B Vol.175-177, pp.410-416, ISSN 0168$583 X$.

Bianconi, M., Bentini, G. G., Chiarini, M., De Nicola, P., Montanari, G. B., Nubile, A. \& Sugliani, S. (2009). Defect engineering and micromachining of Lithium Niobate by ion implantation. Nucl. Instrum. Meth. B Vol.267, No.17, pp.2839-2845.

Borsella, E., Garcia, M. A., Mattei, G., Maurizio, C., Mazzoldi, P., Cattaruzza, E., Gonella, F., Battaglin, G., Quaranta, A. \& D'Acapito, F. (2001). Synthesis of GaN quantum dots by ion implantation in dielectrics. J. Appl. Phys. Vol.90, No.9, pp.4467-4473, ISSN 1089-7550.

Buchal, C., Withrow, S. P., White, C. W. \& Poker, D. B. (1994). Ion implantation of optical materials. Ann. Rev. Mater. Sci. Vol.24, pp.125-158, ISSN 0084-6600.

Buffat, P. \& Borel, J.-P. (1976). Size effect on the melting temperature of gold particles. Phys. Rev. A Vol.13, No.6, pp.2287-2298, ISSN 1094-1622.

Burakowski, T. \& Wierzchon, T. (1998). Implantation Techniques (Ion Implantation). Surface Engineering of Metals: Principles, Equipment, Technologies. CRC Press. (Materials Science \& Technology)., ISBN 9780849382253.

Cao, M., Wang, M. \& Gu, N. (2009). Optimized surface plasmon resonance sensitivity of gold nanoboxes for sensing applications. J. Phys. Chem. C Vol.113, No.4, pp.12171221.

Catchpole, K. R. \& Polman, A. (2008). Plasmonic solar cells. Opt. Express Vol.16, No.26, pp.21793-21800, ISSN 1094-4087.

Cui, Y., Ren, B., Yao, J.-L., Gu, R.-A. \& Tian, Z.-Q. (2006). Synthesis of $\mathrm{Ag}_{\text {core }}-\mathrm{Au}_{\text {shell }}$ bimetallic nanoparticles for immunoassay based on surface-enhanced Raman spectroscopy. J. Phys. Chem. B Vol.110, No.9, pp.4002-4006, ISSN 1520-5207.

D'Orléans, C., Stoquert, J. P., Estournès, C., Cerruti, C., Grob, J. J., Guille, J. L., Haas, F., Muller, D. \& Richard-Plouet, M. (2003). Anisotropy of Co nanoparticles induced by swift heavy ions. Phys. Rev. B Vol.67, No.22, pp.220101, ISSN 1550-235X. 
Davenas, J., Perez, A., Thevenard, P. \& Dupuy, C. H. S. (1973). Correlation between absorption bands and implanted alkali ions in LiF. Phys. Stat. Sol. A Vol.19, No.2, pp.679-686, ISSN 1521-396X.

De, G. (1997). Sol-gel synthesis of metal nanoclusters-silica composite films. J. Sol-Gel Sci. Technol. Vol.11, No.3, pp.289-298, ISSN 1573-4846.

Deying, S., Saito, Y. \& Suganomata, S. (1994). Optical properties of $\mathrm{LiNbO}_{3}$ implanted with $\mathrm{Ag}^{+}$ions. Jpn. J. Appl. Phys. Vol.33, pp.L966-L969, ISSN 0021-4922.

Dhara, S., Sundaravel, B., Ravindran, T. R., Nair, K. G. M., David, C., Panigrahi, B. K., Magudapathy, P. \& Chen, K. H. (2004). "Spillout" effect in gold nanoclusters

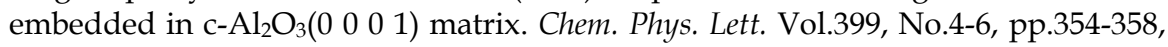
ISSN 0009-2614.

van Dillen, T., Polman, A., Onck, P. R. \& van der Giessen, E. (2005). Anisotropic plastic deformation by viscous flow in ion tracks. Phys. Rev. B Vol.71, No.2, pp.024103.

Ding, I., Zhu, J., Cai, W., Moon, S., Cai, N., Wang, P., Zakeeruddin, S. M., Grätzel, M., Brongersma, M. L., Cui, Y. \& McGehee, M. D. (2011). Plasmonic dye-sensitized solar cells. Adv. Ener. Mater. Vol.1, No.1, pp.52-57, ISSN 1614-6840.

Donnet, C., Marest, G., Moncoffre, N., Tousset, J., Rahioui, A., Esnouf, C. \& Brunel, M. (1991). Copper, iron and zirconium implantation into polycrystalline $\mathrm{a}-\mathrm{Al}_{2} \mathrm{O}_{3}$. Nucl. Instrum. Meth. B Vol.59-60, No.2, pp.1205-1210, ISSN 0168-583X.

Duhan, S., Devi, S. \& Srivastava, M. (2010). Characterization of nanocrystalline $\mathrm{Ag} / \mathrm{SiO}_{2}$ nanocomposites and synthesis by wet chemical method. Ind. J. Pure E Appl. Phys. Vol.48, No.4, pp.271-275, ISSN 0019-5596.

Esparza, R., Ascencio, J. A., Rosas, G., Sánchez Ramírez, J. F., Pal, U. \& Perez, R. (2005). Structure, stability and catalytic activity of chemically synthesized $\mathrm{Pt}, \mathrm{Au}$, and AuPt nanoparticles. J. Nanosci. Nanotechnol. Vol.5, No.4, pp.641-647, ISSN 15334899.

Flytzanis, C., Hache, F., Klein, M. C., Ricard, D. \& Roussignol, P. (1991). Nonlinear optics in composite materials. In: Wolf, E. (Ed.) Progress in Optics. pp 321-411. Elsevier Science Pub Co., ISBN 0444889515.

García-Serrano, J. \& Pal, U. (2003). Synthesis and characterization of Au nanoparticles in $\mathrm{Al}_{2} \mathrm{O}_{3}$ matrix. Int. J. Hydrog. Energy Vol.28, No.6, pp.637-640, ISSN 0360-3199.

Gonella, F., Mattei, G., Mazzoldi, P., Sada, C., Battaglin, G. \& Cattaruzza, E. (1999). Au-Cu alloy nanoclusters in silica formed by ion implantation and annealing in reducing or oxidizing atmosphere. Appl. Phys. Lett. Vol.75, No.1, pp.55-57, ISSN 0003-6951.

Haug, J., Dubiel, M., Kruth, H. \& Hofmeister, H. (2009). Structural characterization of bimetallic Ag-Au nanoparticles in glass. J. Phys.: Conf. Ser. Vol.190, No.1, pp.012124, ISSN 1742-6596.

Hazra, S., Gibaud, A. \& Sella, C. (2004). Tunable absorption of $\mathrm{Au}_{-} \mathrm{Al}_{2} \mathrm{O}_{3}$ nanocermet thin films and its morphology. Appl. Phys. Lett. Vol.85, No.3, pp.395-397, ISSN 00036951.

Hirsch, L. R., Jackson, J. B., Lee, A., Halas, N. J. \& West, J. L. (2003a). A whole blood immunoassay using gold nanoshells. Anal. Chem. Vol.75, No.10, pp.2377-2381, ISSN 1520-6882.

Hirsch, L. R., Stafford, R. J., Bankson, J. A., Sershen, S. R., Rivera, B., Price, R. E., Hazle, J. D., Halas, N. J. \& West, J. L. (2003b). Nanoshell-mediated near-infrared thermal 
therapy of tumors under magnetic resonance guidance. Proc. Natl. Acad. Sci. U.S.A. Vol.100, No.23, pp.13549-13554, ISSN 0027-8424.

Hövel, H., Fritz, S., Hilger, A., Kreibig, U. \& Vollmer, M. (1993). Width of cluster plasmon resonances: Bulk dielectric functions and chemical interface damping. Phys. Rev. B Vol.48, No.24, pp.18178.

Hughes, A. E. (1983). Colloid formation in irradiated insulators. Rad. Eff. Def. Solids Vol.74, No.1-4, pp.57-76, ISSN 0033-7579.

Ikeyama, M., Nakao, S., Tazawa, M., Kadono, K. \& Kamada, K. (2001). Optical property changes of silica glass and sapphire induced by $\mathrm{Cu}$ and $\mathrm{O}$ implantation. Nucl. Instrum. Meth. B Vol.175-177, pp.652-657, ISSN 0168-583X.

Ila, D., Williams, E. K., Sarkisov, S., Poker, D. B. \& Hensley, D. K. (1997). Change in the optical properties of sapphire induced by ion implantation. Mat. Res. Soc. Proc. Vol.504, pp.381-386, ISSN 0272-9172.

Jackson, J. B. \& Halas, N. J. (2004). Surface-enhanced Raman scattering on tunable plasmonic nanoparticle substrates. Proc. Natl. Acad. Sci. U.S.A. Vol.101, No.52, pp.17930-17935, ISSN 0027-8424.

Jiang, T., Miao, L., Tanemura, S., Tanemura, M., Xu, G. \& Wang, R. P. (2009). Tunable Ag surface-plasmon-resonance wavelength and its application on the photochromic behavior of $\mathrm{TiO}_{2}-\mathrm{Ag}$ films. Superlattices Microstruct. Vol.46, No.1-2, pp.159-165, ISSN 0749-6036.

Johannessen, B., Kluth, P., Glover, C. J., de M. Azevedo, G., Llewellyn, D. J., Foran, G. J. \& Ridgway, M. C. (2005). Structural characterization of $\mathrm{Cu}$ nanocrystals formed in $\mathrm{SiO}_{2}$ by high-energy ion-beam synthesis. J. Appl. Phys. Vol.98, No.2, pp.024307, ISSN 0021-8979.

Johnson, P. B. \& Christy, R. W. (1972). Optical constants of the noble metals. Phys. Rev. B Vol.6, No.12, pp.4370-4379, ISSN 1550-235X.

Joseph, B., Sandeep, C. S. S., Sekhar, B. R., Mahapatra, D. P. \& Philip, R. (2007). Nonlinear optical properties of $\mathrm{MeV}$ and $\mathrm{keV}$ ion beam synthesized Ag nanoclusters. Nucl. Instrum. Meth. B Vol.265, No.2, pp.631-636, ISSN 0168-583X.

Kalidindi, S. B. \& Jagirdar, B. R. (2008). Synthesis of Cu@ZnO core-shell nanocomposite through digestive ripening of $\mathrm{Cu}$ and $\mathrm{Zn}$ nanoparticles. J. Phys. Chem. C Vol.112, No.11, pp.4042-4048, ISSN 1932-7447.

Kim, D.-G., Koyama, E., Tokuhisa, H., Koshizaki, N. \& Kim, Y. D. (2008). Tunable aggregation of $\mathrm{Au}$ nanoparticles in $\mathrm{Au} / \mathrm{SiO}_{2}$ composite film and its photoabsorbance. Appl. Phys. A Vol.92, pp.263-266, ISSN 1432-0630.

Klaumünzer, S. \& Schumacher, G. (1983). Dramatic growth of glassy $\mathrm{Pd}_{80} \mathrm{Si}_{20}$ during heavyion irradiation. Phys. Rev. Lett. Vol.51, No.21, pp.1987-1990, ISSN 1079-7114.

Kluth, P., Hoy, B., Johannessen, B., Dunn, S. G., Foran, G. J. \& Ridgway, M. C. (2006). Co-Au core-shell nanocrystals formed by sequential ion implantation into $\mathrm{SiO}_{2}$. Appl. Phys. Lett. Vol.89, No.15, pp.153118, ISSN 0003-6951.

Kono, K., Arora, S. K. \& Kishimoto, N. (2003). Modification in optical properties of negative Cu ion implanted ZnO. Nucl. Instrum. Meth. B Vol.206, pp.291-294, ISSN 0168-583X.

Kooi, B. J., van Veen, A., De Hosson, J. T. M., Schut, H., Fedorov, A. V. \& Labohm, F. (2000). Rectangular nanovoids in helium-implanted and thermally annealed $\mathrm{MgO}(100)$. Appl. Phys. Lett. Vol.76, No.9, pp.1110-1112, ISSN 0003-6951. 
Kreibig, U. \& Vollmer, M. (1995). Optical properties of metal clusters. 1. ed. Berlin, Heidelberg: Springer., ISBN 3540578366.

Kucheyev, S. O., Williams, J. S., Jagadish, C., Zou, J., Evans, C., Nelson, A. J. \& Hamza, A. V. (2003). Ion-beam-produced structural defects in ZnO. Phys. Rev. B Vol.67, No.9, pp.094115, ISSN 1550-235X.

Lifshitz, M. \& Slezov, V. V. (1959). Kinetics of diffusive decomposition of supersaturated solid solutions. Soviet Phys. JETP Vol.35, pp.331-339, ISSN 0038-5646.

Liu, H. B., Pal, U., Medina, A., Maldonado, C. \& Ascencio, J. A. (2005). Structural incoherency and structure reversal in bimetallic Au-Pd nanoclusters. Phys. Rev. B Vol.71, No.7, pp.075403, ISSN 1550-235X.

Liu, H. B., Pal, U., Perez, R. \& Ascencio, J. A. (2006). Structural transformation of Au-Pd bimetallic nanoclusters on thermal heating and cooling: a dynamic analysis. J. Phys. Chem. B Vol.110, No.11, pp.5191-5195, ISSN 1520-6106.

Ma, Z. Y., Dosev, D. \& Kennedy, I. M. (2009). A microemulsion preparation of nanoparticles of europium in silica with luminescence enhancement using silver. Nanotechnol. Vol.20, No.8, pp.085608, ISSN 1361-6528.

Manoilov, E. G. (2009). Optical and photoluminescent properties of $\mathrm{Ag} / \mathrm{Al}_{2} \mathrm{O}_{3}$ nanocomposite films obtained by pulsed laser deposition. Semicond. Phys. Quant. Electron. \& Opt. Vol.12, No.3, pp.298-301, ISSN 1560-8034.

Marques, C., Alves, E., da Silva, R. C., Silva, M. R. \& Stepanov, A. L. (2004). Optical changes induced by high fluence implantation of $\mathrm{Au}$ ions on sapphire. Nucl. Instrum. Meth. $B$ Vol.218, pp.139-144, ISSN 0168-583X.

Mattei, G. (2002). Alloy nanoclusters in dielectric matrix. Nucl. Instrum. Meth. B Vol.191, No.1-4, pp.323-332, ISSN 0168-583X.

Mattei, G., Battaglin, G., Bello, V., De Marchi, G., Maurizio, C., Mazzoldi, P., Parolin, M. \& Sada, C. (2003a). De-alloying behaviour of metal nanoclusters in $\mathrm{SiO}_{2}$ upon irradiation and thermal treatments. J. Non-Cryst. Sol. Vol.322, No.1-3, pp.17-21, ISSN 0022-3093.

Mattei, G., Bello, V., Mazzoldi, P., Pellegrini, G., Sada, C., Maurizio, C. \& Battaglin, G. (2005). Modification of composition and structure of bimetallic nanocluster in silica by ion beam irradiation. Nucl. Instrum. Meth. B Vol.240, No.1-2, pp.128-132, ISSN 0168$583 X$.

Mattei, G., Marchi, G. D., Maurizio, C., Mazzoldi, P., Sada, C., Bello, V. \& Battaglin, G. (2003b). Chemical- or radiation-assisted selective dealloying in bimetallic nanoclusters. Phys. Rev. Lett. Vol.90, No.8, pp.085502, ISSN 1079-7114.

Mazzoldi, P. (1987). Ion beam modifications of insulators. New York: Elsevier Science Ltd., ISBN 044442816X.

Mazzoldi, P., Arnold, G. W., Battaglin, G., Gonella, F. \& Haglund, R. F. (1996). Metal nanocluster formation by ion implantation in silicate glasses: Nonlinear optical applications. J. Nonlinear Opt. Phys. Mater. Vol.5, No.2, pp.285-330, ISSN 0218-8635.

Mendoza-Galván, A., Trejo-Cruz, C., Lee, J., Bhattacharyya, D., Metson, J., Evans, P. J. \& Pal, U. (2006). Effect of metal-ion doping on the optical properties of nanocrystalline ZnO thin films. J. Appl. Phys. Vol.99, No.1, pp.014306, ISSN 0021-8979.

Mishra, Y. K., Mohapatra, S., Singhal, R., Avasthi, D. K., Agarwal, D. C. \& Ogale, S. B. (2008). Au-ZnO: A tunable localized surface plasmonic nanocomposite. Appl. Phys. Lett. Vol.92, No.4, pp.043107, ISSN 0003-6951. 
Mohapatra, S., Ghatak, J., Joseph, B., Lenka, H. P., Kuiri, P. K. \& Mahapatra, D. P. (2007). Anomalous diffusion of $\mathrm{Au}$ in mega-electron-volt $\mathrm{Au}$ implanted $\mathrm{SiO}_{2} \mathrm{Si}(100)$. J. Appl. Phys. Vol.101, No.6, pp.063542, ISSN 0021-8979.

Nakao, S., Nonami, T., Jin, P., Miyagawa, Y. \& Miyagawa, S. (2000). High-energy metal ion implantation into titanium dioxide films. Surf. Coat. Technol. Vol.128-129, pp.446449, ISSN 0257-8972.

Norton, D. P., Overberg, M. E., Pearton, S. J., Pruessner, K., Budai, J. D., Boatner, L. A., Chisholm, M. F., Lee, J. S., Khim, Z. G., Park, Y. D. \& Wilson, R. G. (2003). Ferromagnetism in cobalt-implanted ZnO. Applied Physics Letters Vol.83, No.26, pp.5488-5490, ISSN 0003-6951.

Ohkubo, M. \& Suzuki, N. (1988). Morphology of small gold crystals formed inside sapphire by ion implantation. Phil. Mag. Lett. Vol.57, No.5, pp.261-265, ISSN 1362-3036.

Okumu, J., Dahmen, C., Sprafke, A. N., Luysberg, M., von Plessen, G. \& Wuttig, M. (2005). Photochromic silver nanoparticles fabricated by sputter deposition. J. Appl. Phys. Vol.97, No.9, pp.094305, ISSN 0021-8979.

Oliver, A., Cheang-Wong, J. C., Roiz, J., Rodríguez-Fernández, L., Hernández, J. M., CrespoSosa, A. \& Muñoz, E. (2002). Metallic nanoparticle formation in ion-implanted silica after thermal annealing in reducing or oxidizing atmospheres. Nucl. Instrum. Meth. B Vol.191, No.1-4, pp.333-336, ISSN 0168-583X.

Pal, U., Aguila-Almanza, E., Vázquez-Cuchillo, O., Koshizaki, N., Sasaki, T. \& Terauchi, S. (2001). Preparation of $\mathrm{Au} / \mathrm{ZnO}$ nanocomposites by radio frequency co-sputtering. Sol. Energy Mater. Sol. Cells Vol.70, No.3, pp.363-368, ISSN 0927-0248.

Pal, U., Bautista-Hernández, A., Rodríguez-Fernández, L. \& Cheang-Wong, J. . (2000). Effect of thermal annealing on the optical properties of high-energy $\mathrm{Cu}$-implanted silica glass. J. Non-Cryst. Sol. Vol.275, No.1-2, pp.65-71, ISSN 0022-3093.

Pan, J., Wang, H., Takeda, Y., Umeda, N., Kono, K., Amekura, H. \& Kishimoto, N. (2007). Effect of indentation and annealing on $2 \mathrm{MeV} \mathrm{Cu}$ ion-implanted $\mathrm{SiO}_{2}$. Nucl. Instrum. Meth. B Vol.257, No.1-2, pp.585-588, ISSN 0168-583X.

Pavesi, L., Dal Negro, L., Mazzoleni, C., Franzo, G. \& Priolo, F. (2000). Optical gain in silicon nanocrystals. Nature Vol.408, No.6811, pp.440-444, ISSN 0028-0836.

Pellegrini, G., Bello, V., Mattei, G. \& Mazzoldi, P. (2007a). Local-field enhancement and plasmon tuning in bimetallic nanoplanets. Opt. Express Vol.15, No.16, pp.1009710102, ISSN 1094-4087.

Pellegrini, G., Mattei, G., Bello, V. \& Mazzoldi, P. (2007b). Interacting metal nanoparticles: Optical properties from nanoparticle dimers to core-satellite systems. Mater. Sci. Eng. C Vol.27, No.5-8, pp.1347-1350, ISSN 0928-4931.

Penninkhof, J. J., van Dillen, T., Roorda, S., Graf, C., van Blaaderen, A., Vredenberg, A. M. \& Polman, A. (2006). Anisotropic deformation of metallo-dielectric core-shell colloids under MeV ion irradiation. Nucl. Instrum. Meth. B Vol.242, No.1-2, pp.523-529, ISSN 0168-583X.

Peña, O., Pal, U., Rodíguez-Fernández, L., Silva-Pereyra, H. G., Rodríguez-Iglesias, V., Cheang-Wong, J. C., Arenas-Alatorre, J. \& Oliver, A. (2009). Formation of Au-Ag core-shell nanostructures in silica matrix by sequential ion implantation. J. Phys. Chem. C Vol.113, No.6, pp.2296-2300, ISSN 1932-7447.

Peña, O., Rodríguez-Fernández, L., Cheang-Wong, J. C., Santiago, P., Crespo-Sosa, A., Muñoz, E. \& Oliver, A. (2006). Characterization of nanocluster formation in $\mathrm{Cu}$ - 
implanted silica: Influence of the annealing atmosphere and the ion fluence. J. NonCryst. Sol. Vol.352, No.4, pp.349-354, ISSN 0022-3093.

Peña-Rodríguez, O. \& Pal, U. (2010). Geometrical tunability of linear optical response of silica-gold double concentric nanoshells. J. Phys. Chem. C Vol.114, No.10, pp.44144417, ISSN 1932-7447.

Peña-Rodríguez, O. \& Pal, U. (2011a). Au@Ag core-shell nanoparticles: Efficient allplasmonic Fano-resonance generators. Nanoscale Vol.3, No.9, pp.3609-3612, ISSN 2040-3364.

Peña-Rodríguez, O. \& Pal, U. (2011b). Enhanced plasmonic behavior of bimetallic (Ag-Au) multilayered spheres. Nanoscale Res. Lett. Vol.6, No.1, pp.279, ISSN 1556-276X.

Peña-Rodríguez, O., Pal, U., Campoy-Quiles, M., Rodríguez-Fernández, L., Garriga, M. \& Alonso, M. I. (2011a). Enhanced Fano resonance in asymmetrical Au:Ag heterodimers. J. Phys. Chem. C Vol.115, No.14, pp.6410-6414, ISSN 1932-7447.

Peña-Rodríguez, O., Pal, U., Rodríguez-Iglesias, V., Rodríguez-Fernández, L. \& Oliver, A. (2011b). Configuring Au and Ag nanorods for sensing applications. J. Opt. Soc. Am. $B$ Vol.28, No.4, pp.714-720, ISSN 1520-8540.

Picraux, S. T. (1984). Ion implantation in metals. Ann. Rev. Mater. Sci. Vol.14, pp.335-372, ISSN 0084-6600.

Ren, F., Jiang, C. Z., Wang, Y. H., Wang, Q. Q. \& Wang, J. B. (2006). The problem of core/shell nanoclusters formation during ion implantation. Nucl. Instrum. Meth. B Vol.245, No.2, pp.427-430, ISSN 0168-583X.

Rivera, A., Crespillo, M. L., Olivares, J., García, G. \& Agulló-López, F. (2010). Effect of defect accumulation on ion-beam damage morphology by electronic excitation in lithium niobate: A Monte Carlo approach. Nucl. Instrum. Meth. B Vol.268, No.13, pp.22492256, ISSN 0168-583X.

Rodríguez-Iglesias, V., Peña-Rodríguez, O., Silva-Pereyra, H. G., Rodríguez-Fernández, L., Cheang-Wong, J. C., Crespo-Sosa, A., Reyes-Esqueda, J. A. \& Oliver, A. (2010a). Tuning the aspect ratio of silver nanospheroids embedded in silica. Opt. Lett. Vol.35, No.5, pp.703-705, ISSN 1539-4794.

Rodríguez-Iglesias, V., Peña-Rodríguez, O., Silva-Pereyra, H. G., Rodríguez-Fernández, L., Kellermann, G., Cheang-Wong, J. C., Crespo-Sosa, A. \& Oliver, A. (2010b). Elongated gold nanoparticles obtained by ion implantation in silica: Characterization and T-matrix simulations. J. Phys. Chem. C Vol.114, No.2, pp.746751, ISSN 1932-7447.

Roiz, J., Oliver, A., Munoz, E., Rodriguez-Fernandez, L., Hernandez, J. M. \& Cheang-Wong, J. C. (2004). Modification of the optical properties of Ag-implanted silica by annealing in two different atmospheres. J. Appl. Phys. Vol.95, No.4, pp.1783-1791, ISSN 1089-7550.

Ryasnyansky, A., Palpant, B., Debrus, S., Ganeev, R., Stepanov, A., Can, N., Buchal, C. \& Uysal, S. (2005). Nonlinear optical absorption of $\mathrm{ZnO}$ doped with copper nanoparticles in the picosecond and nanosecond pulse laser field. Appl. Opt. Vol.44, No.14, pp.2839-2845, ISSN 1539-4522.

Sangpour, P., Hashemi, F. \& Moshfegh, A. Z. (2010). Photoenhanced degradation of methylene blue on cosputtered $\mathrm{M}: \mathrm{TiO}_{2}(\mathrm{M}=\mathrm{Au}, \mathrm{Ag}, \mathrm{Cu})$ nanocomposite systems: A comparative study. J. Phys. Chem. C Vol.114, No.33, pp.13955-13961, ISSN 19327447. 
Serna, R., Suárez-García, A., Afonso, C. N. \& Babonneau, D. (2006). Optical evidence for reactive processes when embedding $\mathrm{Cu}$ nanoparticles in $\mathrm{Al}_{2} \mathrm{O}_{3}$ by pulsed laser deposition. Nanotechnol. Vol.17, No.18, pp.4588-4593, ISSN 1361-6528.

Shan, G., Xu, L., Wang, G. \& Liu, Y. (2007). Enhanced raman scattering of ZnO quantum dots on silver colloids. J. Phys. Chem. C Vol.111, No.8, pp.3290-3293, ISSN 19327447.

Sonawane, R. S. \& Dongare, M. K. (2006). Sol-gel synthesis of $\mathrm{Au} / \mathrm{TiO}_{2}$ thin films for photocatalytic degradation of phenol in sunlight. J. Mol. Catal. A: Chem. Vol.243, No.1, pp.68-76, ISSN 1381-1169.

Steiner, G., Pham, M. T., Kuhne, C. \& Salzer, R. (1998). Surface plasmon resonance within ion implanted silver clusters. Fresenius J. Anal. Chem. Vol.362, No.1, pp.9-14, ISSN 1432-1130.

Stepanov, A. \& Popok, V. (2003). Synthesis of $\mathrm{Cu}$ nanoparticles in $\mathrm{Al}_{2} \mathrm{O}_{3}$ by ion implantation and subsequent laser annealing.(Duggan, J. L., Morgan, I. L., \& Hall, M., Eds.) AIP Conf. Proc. Vol.680, No.1, pp.601-604, ISSN 0094-243X.

Stepanov, A. ., Kreibig, U., Hole, D. ., Khaibullin, R. ., Khaibullin, I. . \& Popok, V. . (2001). Laser annealing of sapphire with implanted copper nanoparticles. Nucl. Instrum. Meth. B Vol.178, No.1-4, pp.120-125, ISSN 0168-583X.

Stepanov, A. L. \& Khaibullin, I. B. (2005). Fabrication of metal nanoparticles in sapphire by low-energy ion implantation. Rev. Adv. Mater. Sci. Vol.9, No.2, pp.109-129, ISSN 1605-8127.

Stepanov, A. L., Abdullin, S. N., Khaibullin, R. I., Valeev, V. F., Osin, Y. N., Bazarov, V. V. \& Khaibullin, I. B. (1995). Ion synthesis of colloidal silver nanoclusters in the organic substrate. MRS Online Proceedings Library Vol.392, pp.267-272, ISSN 1946-4274.

Stepanov, A. L., Khaibullin, R. I., Can, N., Ganeev, R. A., Ryasnyansky, A. I., Buchal, C. \& Uysal, S. (2004). Application of ion implantation for synthesis of copper nanoparticles in a zinc oxide matrix for obtaining new nonlinear optical materials. Tech. Phys. Lett. Vol.30, No.10, pp.846-849, ISSN 1090-6533.

Subramanian, V., Wolf, E. E. \& Kamat, P. V. (2004). Catalysis with $\mathrm{TiO}_{2} /$ gold nanocomposites. Effect of metal particle size on the fermi level equilibration. J. Am. Chem. Soc. Vol.126, No.15, pp.4943-4950, ISSN 0002-7863.

Sun, Y. \& Xia, Y. (2002). Increased sensitivity of surface plasmon resonance of gold nanoshells compared to that of gold solid colloids in response to environmental changes. Anal. Chem. Vol.74, No.20, pp.5297-5305, ISSN 1520-6882.

Takeda, Y., Plaksin, O. A., Kono, K. \& Kishimoto, N. (2005). Nonlinear optical properties of $\mathrm{Cu}$ nanoparticles in various insulators fabricated by negative ion implantation. Surf. Coat. Technol. Vol.196, No.1-3, pp.30-33, ISSN 0257-8972.

Takeda, Y., Plaksin, O. A., Wang, H., Kono, K., Umeda, N. \& Kishimoto, N. (2006). Surface plasmon resonance of $\mathrm{Au}$ nanoparticles fabricated by negative ion implantation and grid structure toward plasmonic applications. Opt. Rev. Vol.13, No.4, pp.231234, ISSN 1349-9432.

Tihay, F., Pourroy, G., Richard-Plouet, M., Roger, A. C. \& Kiennemann, A. (2001). Effect of Fischer-Tropsch synthesis on the microstructure of Fe-Co-based metal/spinel composite materials. Appl. Catal. A Vol.206, No.1, pp.29-42, ISSN 0926-860X. 
Tohidi, S. H., Grigoryan, G., Sarkeziyan, V. \& Ziaie, F. (2010). Effect of concentration and thermal treatment on the properties of sol-gel derived $\mathrm{CuO} / \mathrm{SiO}_{2}$ nanostructure. Iran. J. Chem. Chem. Eng. Vol.29, No.2, pp.27-35, ISSN 1021-9986.

Townsend, P. D. (1987). Optical effects of ion implantation. Rep. Prog. Phys. Vol.50, No.5, pp.501-558, ISSN 1361-6633.

Trinkaus, H. \& Ryazanov, A. I. (1995). Viscoelastic model for the plastic flow of amorphous solids under energetic ion bombardment. Phys. Rev. Lett. Vol.74, No.25, pp.50725075, ISSN 1079-7114.

Tsuji, H., Sagimori, T., Kurita, K., Gotoh, Y. \& Ishikawa, J. (2002). Surface modification of $\mathrm{TiO}_{2}$ (rutile) by metal negative ion implantation for improving catalytic properties. Surf. Coat. Technol. Vol.158-159, No.0, pp.208-213, ISSN 0257-8972.

Vazquez-Cuchillo, O., Bautista-Hernandez, A., Pal, U. \& Meza-Montes, L. (2001). Study of the optical absorption of $\mathrm{Cu}$ clusters in the $\mathrm{Cu} / \mathrm{ZnO}$ system. Mod. Phys. Lett. B Vol.15, No.17-19, pp.625-629, ISSN 0217-9849.

Wang, C. M. (2004). Microstructure of precipitated Au nanoclusters in $\mathrm{TiO}_{2}$. J. Appl. Phys. Vol.95, No.12, pp.8185, ISSN 0021-8979.

Wang, C. M., Zhang, Y., Shutthanandan, V., Baer, D. R., Weber, W. J., Thomas, L. E., Thevuthasan, S. \& Duscher, G. (2005). Self-assembling of nanocavities in $\mathrm{TiO}_{2}$ dispersed with Au nanoclusters. Phys. Rev. B Vol.72, No.24, pp.245421, ISSN 1550235X.

Wang, D.-Y., Lin, H.-C. \& Yen, C.-C. (2006). Influence of metal plasma ion implantation on photo-sensitivity of anatase $\mathrm{TiO}_{2}$ thin films. Thin Solid Films Vol.515, No.3, pp.10471052, ISSN 0040-6090.

Wang, X.-H., Shi, J., Dai, S. \& Yang, Y. (2003). A sol-gel method to prepare pure and gold colloid doped ZnO films. Thin Solid Films Vol.429, No.1-2, pp.102-107, ISSN 00406090.

White, C. W., Budai, J. D., Withrow, S. P., Zhu, J. G., Sonder, E., Zuhr, R. A., Meldrum, A., Hembree, J., Henderson, D. O. \& Prawer, S. (1998). Encapsulated semiconductor nanocrystals formed in insulators by ion beam synthesis. Nucl. Instrum. Meth. B Vol.141, No.1-4, pp.228-240, ISSN 0168-583X.

White, C. W., Thomas, D. K., Hensley, D. K., Zuhr, R. A., McCallum, J. C., Pogany, A., Haglund, R. F., Magruder, R. H. \& Yang, L. (1993). Colloidal Au and Ag precipitates formed in $\mathrm{Al}_{2} \mathrm{O}_{3}$ by ion implantation and annealing. Nanostr. Mater. Vol.3, No.1-6, pp.447-457, ISSN 0965-9773.

White, C. W., Thomas, D. K., Zuhr, R. A., McCallum, J. C., Pogany, A., Haglund, R. F., Magruder, R. H. \& Yang, L. (1992). Modification of the optical properties of $\mathrm{Al}_{2} \mathrm{O}_{3}$ by ion implantation. Mat. Res. Soc. Proc. Vol.268, pp.331-336, ISSN 0272-9172.

Xiao, X. H., Ren, F., Wang, J. B., Liu, C. \& Jiang, C. Z. (2007). Formation of aligned silver nanoparticles by ion implantation. Mater. Lett. Vol.61, No.22, pp.4435-4437, ISSN 0167-577X.

Xiao, X. H., Ren, F., Zhou, X. D., Peng, T. C., Wu, W., Peng, X. N., Yu, X. F. \& Jiang, C. Z. (2010). Surface plasmon-enhanced light emission using silver nanoparticles embedded in ZnO. Appl. Phys. Lett. Vol.97, No.7, pp.071909, ISSN 0003-6951.

$\mathrm{Xu}$, J.-X., Ren, F., Fu, D.-J. \& Jiang, C.-Z. (2006). Effect of thermal annealing on the optical properties of low-energy Cu-implanted silica glass. Physica B Vol.373, No.2, pp.341345, ISSN 0921-4526. 
Yasuda, H. \& Mori, H. (1994). Cluster-size dependence of alloying behavior in gold clusters. Z. Phys. D Vol.31, No.1-2, pp.131-134, ISSN 1434-6079.

Zeng, H., Qiu, J., Jiang, X., Zhu, C. \& Gan, F. (2004). Effect of $\mathrm{Al}_{2} \mathrm{O}_{3}$ on the precipitation of Ag nanoparticles in silicate glasses. J. Cryst. Growth Vol.262, No.1-4, pp.255-258, ISSN 0022-0248.

Zhang, J. Z. (2010). Biomedical applications of shape-controlled plasmonic nanostructures: a case study of hollow gold nanospheres for photothermal ablation therapy of cancer. J. Phys. Chem. Lett. Vol.1, No.4, pp.686-695, ISSN 1948-7185.

Zheng, Y., Chen, C., Zhan, Y., Lin, X., Zheng, Q., Wei, K. \& Zhu, J. (2008). Photocatalytic activity of $\mathrm{Ag} / \mathrm{ZnO}$ heterostructure nanocatalyst: Correlation between structure and property. J. Phys. Chem. C Vol.112, No.29, pp.10773-10777, ISSN 1932-7447.

Zhou, X. D., Xiao, X. H., Xu, J. X., Cai, G. X., Ren, F. \& Jiang, C. Z. (2011). Mechanism of the enhancement and quenching of $\mathrm{ZnO}$ photoluminescence by $\mathrm{ZnO}-\mathrm{Ag}$ coupling. Euro Phys. Lett. Vol.93, No.5, pp.6, ISSN 1286-4854.

Zhu, S., Sun, K., Wang, L. M., Ewing, R. C. \& Fromknecht, R. (2006). TEM characterization of Au nano-particles in $\mathrm{TiO}_{2}$ single crystals by ion implantation. Nucl. Instrum. Meth. B Vol.242, No.1-2, pp.152-156, ISSN 0168-583X.

Ziegler, J. SRIM - The Stopping and Range of Ions in Matter: http://www.srim.org/. [online] (2008). Available from: http://www.srim.org/. [Accessed 2009-09-16].

Ziegler, J. F. (1985). The stopping and range of ions in solids. Pergamon Pr., ISBN 008021603X. 


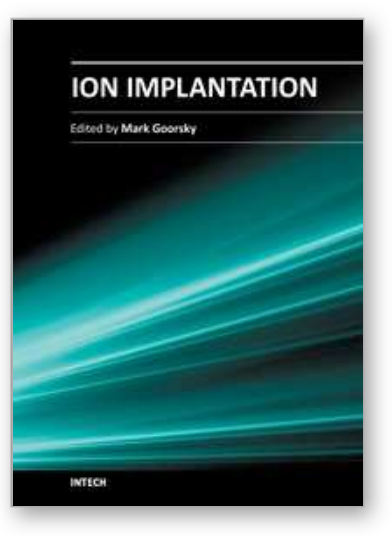

\author{
Ion Implantation \\ Edited by Prof. Mark Goorsky
}

ISBN 978-953-51-0634-0

Hard cover, 436 pages

Publisher InTech

Published online 30, May, 2012

Published in print edition May, 2012

Ion implantation presents a continuously evolving technology. While the benefits of ion implantation are well recognized for many commercial endeavors, there have been recent developments in this field. Improvements in equipment, understanding of beam-solid interactions, applications to new materials, improved characterization techniques, and more recent developments to use implantation for nanostructure formation point to new directions for ion implantation and are presented in this book.

\title{
How to reference
}

In order to correctly reference this scholarly work, feel free to copy and paste the following:

Umapada Pal and Ovidio Peña Rodríguez (2012). Ion Implantation for the Fabrication of Plasmonic Nanocomposites: A Brief Review, Ion Implantation, Prof. Mark Goorsky (Ed.), ISBN: 978-953-51-0634-0, InTech, Available from: http://www.intechopen.com/books/ion-implantation/ion-implantation-for-the-fabricationof-plasmonic-nanocomposites-a-brief-review

\section{INTECH}

open science | open minds

\author{
InTech Europe \\ University Campus STeP Ri \\ Slavka Krautzeka 83/A \\ 51000 Rijeka, Croatia \\ Phone: +385 (51) 770447 \\ Fax: +385 (51) 686166 \\ www.intechopen.com
}

\author{
InTech China \\ Unit 405, Office Block, Hotel Equatorial Shanghai \\ No.65, Yan An Road (West), Shanghai, 200040, China \\ 中国上海市延安西路65号上海国际贵都大饭店办公楼 405 单元 \\ Phone: +86-21-62489820 \\ Fax: $+86-21-62489821$
}


(C) 2012 The Author(s). Licensee IntechOpen. This is an open access article distributed under the terms of the Creative Commons Attribution 3.0 License, which permits unrestricted use, distribution, and reproduction in any medium, provided the original work is properly cited. 